\title{
Virtual industrial water usage and wastewater generation in the Middle East/North African region
}

\section{S. R. Sakhel ${ }^{1}$, S.-U. Geissen ${ }^{2}$, and A. Vogelpohl ${ }^{1}$}

${ }^{1}$ Institut fuer Thermische Verfahrens-und Prozesstechnik, Technische Universitaet Clausthal, Leibnizstrasse 15, 38678 Clausthal-Zellerfeld, Germany

${ }^{2}$ Technische Universitaet Berlin, Institut fuer Technischen Umweltschutz, FG Umweltverfahrenstechnik, Strasse des 17. Juni 135, 10623 Berlin, Germany

Received: 2 December 2012 - Accepted: 8 January 2013 - Published: 22 January 2013 Correspondence to: S. R. Sakhel (simonsakhel@ hotmail.com)

Published by Copernicus Publications on behalf of the European Geosciences Union.
Virtual industrial water usage and wastewater generation

S. R. Sakhel et al.

\section{Title Page}

\section{Abstract}

Conclusions

Tables

14

4

Back
Introduction

References

\section{Figures}

$\rightarrow$ I

Close

\section{Full Screen / Esc}

Printer-friendly Version

Interactive Discussion 


\section{Abstract}

This study deals with the quantification of volumes of water usage, wastewater generation, virtual water export, and wastewater generation from export for eight export relevant industries present in the Middle East/North Africa (MENA). It shows that about 53400 million $\mathrm{m}^{3}$ of water is used per annum while around 793 million $\mathrm{m}^{3}$ of wastewater is generated from products that are meant for domestic consumption and export. The difference between volumes of water usage and wastewater generation is due to water evaporation or injecting underground (oil wells pressure maintenance). The wastewater volume generated from production represents a population equivalent of 15.5 million in terms of wastewater quantity and 30.4 million in terms of BOD. About 409 million $\mathrm{m}^{3}$ of virtual water flows from MENA to EU27 (resulting from export of eight commodities) which is equivalent to $12.1 \%$ of the water usage of those industries and Libya is the largest virtual water exporter (about 87 million $\mathrm{m}^{3}$ ). Crude oil and refined petroleum products represent about $89 \%$ of the total virtual water flow, fertilizers represent around $1510 \%$ and $1 \%$ remaining industries. EU27 poses the greatest indirect pressure on the Kuwaiti hydrological system where the virtual water export represents about $96 \%$ of the actual renewable water resources in this country. The Kuwaiti crude oil water use in relation to domestic water withdrawal is about $89 \%$ which is highest among MENA countries. Pollution of water bodies, in terms of BOD, due to production is very relevant for crude oil, slaughterhouses, refineries, olive oil, and tanneries while pollution due to export to EU27 is most relevant for crude oil industry and olive oil mills.

\section{Introduction}

The region of the Middle East and North Africa (MENA) is the most water scarce region in the world (MENA countries in this study include: Algeria, Bahrain, Egypt, Iran, Iraq, Israel, Jordan, Kuwait, Lebanon, Libya, Morocco, Oman, Qatar, Saudi Arabia, Syria, Tunisia, United Arab Emirates (UAE), and Yemen). In the MENA region including
HESSD

10, 999-1039, 2013

\section{Virtual industrial water usage and wastewater generation}

S. R. Sakhel et al.

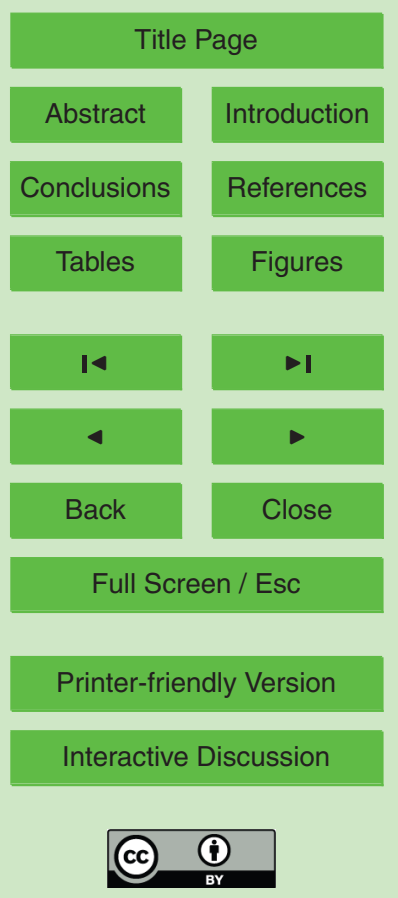


Palestinian Territories and Malta (P\&M) less than $1 \%$ of the world's renewable freshwater is available (Khedr, 2006). The demand for water in this region began to exceed supply in the early 1970's. In Jordan, for example, the demand is higher than supply and the gap is only partially fulfilled through pumping from non-renewable aquifers, desali5 nation and overexploitation of renewable aquifers (Wikipedia (1), 2011). The water that is supplied in this country comes from groundwater (58\%), surface water (32\%), and treated sewage wastewater (10\%) used solely for irrigation (Environmental Statistics, 2004). As for Egypt, the demand is $25 \%$ higher than the available water resources and the gap is satisfied through recycling of agricultural drainage water and trapping water 10 losses (Gad and Ali, 2009). The Kingdom of Saudi Arabia is also a water deficit country. It was reported, for the year 1999, that this water deficit has not been solved (Berman and Winbey, 1999). In this Kingdom the demand is satisfied largely from groundwater resources followed by desalination of seawater and recycling treated wastewater used for agriculture and industry (Abderrahman, undated).

15 Some countries of MENA (P\&M) have adequate quantities of renewable water while others have low levels of renewable water resources. The water availability (here water availability is taken as the water not yet exploited in a given year) is highest in Iran which is around $6.5 \times 10^{10} \mathrm{~m}^{3}$ and lowest in Saudi Arabia which is about $-1.5 \times 10^{10} \mathrm{~m}^{3}$ (data extracted from FAO AQUASTAT 2005 (FAOA2005) and FAO AQUASTAT 2007 (FAOA2007)). About $8 \%$ of total water abstraction in the MENA countries for the year 2000 is due to domestic water withdrawal (FAOA2005). This corresponds to an average of about $179 \mathrm{Lday}^{-1}$ for every inhabitant (FAOA2005, Population Division of the Department of Economic and Social Affairs of the United Nations Secretariat, 2007). This average does not take into account the Unaccounted For Water (UFW). There is a large amount of water lost during distribution. The percentage of UFW ranges between $11.5 \%$ (Israel) to more than $50 \%$ (Iraq). It can be estimated that this loss is about $1.35 \times 10^{10} \mathrm{~m}^{3}$ and the average daily amount of water actually used by every inhabitant for the year 2000 is $118 \mathrm{~L}$. The supply of urban water is intermittent in most of the cities of the MENA (P\&M) region. This is very obvious in the summer, where the
HESSD

10, 999-1039, 2013

\section{Virtual industrial water usage and wastewater generation}

S. R. Sakhel et al.

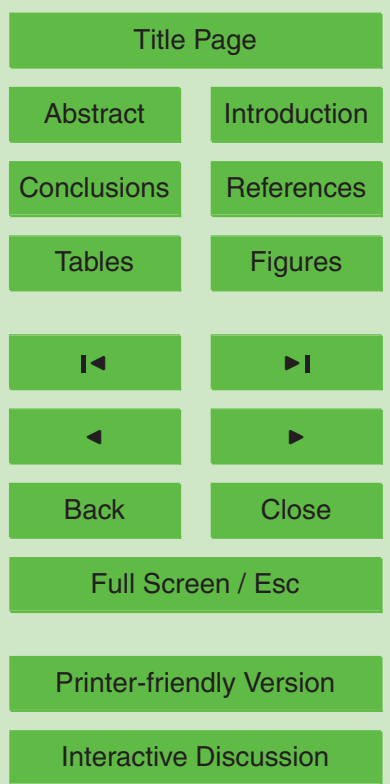


municipal water is pumped to the households only once or twice a week, the rest of the days being turned off. There are 45 million people in the MENA (P\&M) region that still lack adequate access to safe drinking water (Khedr, 2006).

"Virtual water" is an important term to the present research and was introduced in 51993 (Allan, 1993). It is defined as the water that is required to produce agricultural or industrial goods. This term is a tool that can be used to achieve an objective distribution of water resources around the world. There have been efforts to quantify the virtual water flows between nations in the past few years. These efforts showed that the global sum of international virtual water flows must exceed $1.0 \times 10^{12} \mathrm{~m}^{3} \mathrm{yr}^{-1}$ (Hoekstra and 10 Hung, 2002; Chapagain and Hoekstra, 2003, 2004; Zimmer and Renault, 2003; Oki et al., 2003). The first quantification of international virtual water flows has been done by Hoekstra and Hung (2002). Their estimations showed that the global volume of 38 crop-related virtual water trade between nations was $6.95 \times 10^{11} \mathrm{~m}^{3} \mathrm{yr}^{-1}$ in average over the period 1995-1999. The total water use by crops in the world has been estimated at $155.40 \times 10^{12} \mathrm{~m}^{3} \mathrm{yr}^{-1}$ (Rockström and Gordon, 2001). This means that $13 \%$ of water used for the production of 38 primary crops in the world is not used for domestic consumption but for export (in virtual form).

A recent study on the quantification of international virtual water flows has also been done by Chapagain and Hoekstra (2004). This study was built on two earlier ones (Hoekstra and Hung, 2002; Chapagain and Hoekstra, 2003) but improvements and extensions were made. It showed that the global virtual water flow related to trade of crop products, livestock products, and industrial products are $9.87,2.76$, and $3.62 \times$ $10^{11} \mathrm{~m}^{3} \mathrm{yr}^{-1}$ in average over the period $1997-2001$, respectively. About $61 \%$ of virtual water flows between countries are related to international trade of crop products. Trade in livestock products and industrial products contribute $17 \%$ and $22 \%$, respectively. There are no publications existing that give percentages of virtual water made of the different products for the region of MENA.

The aim of this paper is to quantitatively assess the volumes of water used, wastewater generated, virtual water exported to EU27, and wastewater generated from export
HESSD

10, 999-1039, 2013

\section{Virtual industrial water usage and wastewater generation}

S. R. Sakhel et al.

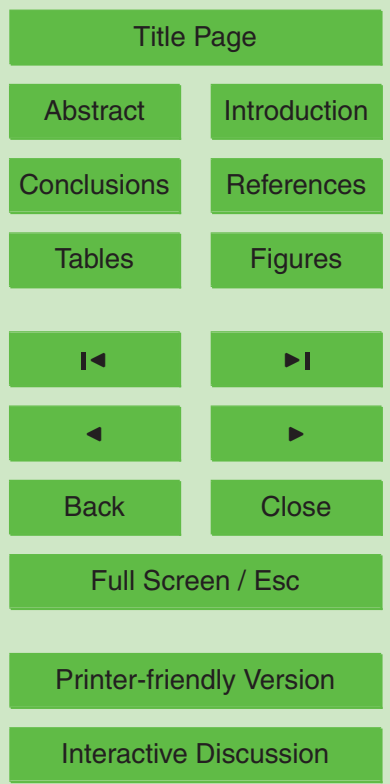


for eight export relevant industries in MENA. Another goal is to shed light on the industries that are most relevant in terms of pollution due to production and export, and indirect water consumption by EU27 through import of goods from MENA. This study quantifies and evaluates the indirect pressure that EU27 poses on the hydrological 5 systems of the different MENA countries.

\section{Methodology and assumptions}

The eight export relevant industries that have been selected are: crude oil, petroleum refineries, fertilizers, pig iron, potash, leather, olive oil, and slaughterhouses. The first five aforementioned industries have been selected because they are considered ma10 jor industries in the relevant countries (Violides-Business Development-Middle East \& North Africa; Al-Hakawati; The Federation of Pakistan Chambers of Commerce and Industry; Taib, 2007; Yager, 2005; Mobbs, 2005). An industry is considered a major one based on factors such as its contribution to the gross domestic product (GDP), the percentage of the population it employs, and its gross business receipts (Economy Watch, 15 undated). These three economic indicators show the importance of the five industries (crude oil, refineries, fertilizers, pig iron and potash). The major industry of a country is classified after ranking all its industries according to their contribution to the Gross Domestic Product (GDP) and the percentage of the population it employs. The industries at the top of the list would be the major ones (personal communications: Clark, 2011; Biddle, 2011). There is no criteria for classifying a whole industry as being major or not (personal communications: Whiteman, 2011; Blair, 2011) but there are criteria for classifying the companies that control these industries as being large or not. Almost all the companies that control the five industries are classified as large sized enterprises according to European criteria (European Commission-Enterprise and Industry 25 Publications, 2005). This would be another reason for selecting those five industries. The criteria that have been used are the turnover (revenue) and the staff headcount (employees). If the company's turnover is more than 70.1 million US $\$$ and the staff

\section{HESSD}

10, 999-1039, 2013

\section{Virtual industrial water usage and wastewater generation}

S. R. Sakhel et al.

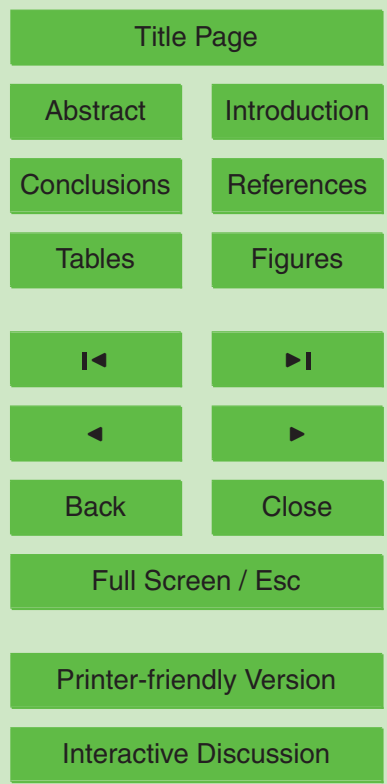


headcount is more than 250 the company would be classified as a major one. Table 1 lists some of the MENA companies with their revenues and staff headcount.

The selection of leather and olive oil industries could be justified from an economic and environmental point of view. The olive sector in Morocco and Tunisia provides employment for more than 3 million people which is about $19.5 \%$ of the total labour force. It generates earnings of about half a billion US \$ from export of Tunisian olive oil ( $1.26 \%$ of the GDP) and 124 million US \$ from export of Moroccan table olives and olive oil ( $0.14 \%$ of the GDP) (International Olive Oil Council (IOOC)(1), IOOC(2)). The leather and shoe sector in Egypt (the fifth largest industrial sector in Egypt) and Tunisia 10 employ thousands of people which is about $1 \%$ of the total labour force, and provide yearly about 570 million US \$ for Tunisia from export (1.44\% of the GDP) (ECOTAN - Demonstration of Clean Technologies in Tanning Processes. In Morocco the tanning industry is one of the most active sectors in the country playing an important role in the overall economy (Ministry of Environment-Spain, 2000). The olive oil industries in 15 Israel and Lebanon, and the leather industries in Algeria, Jordan, and Israel have been selected due to environmental reasons. Olive oil mill effluent is among the strongest industrial wastewaters (e.g. COD: $6.4-162 \mathrm{gL}^{-1}$, BOD: $1.5-100 \mathrm{gL}^{-1}$, Phenols: $4.5 \mathrm{gL}^{-1}$ ) and tanneries produce liquid emissions that are very harmful to the environment due to the heavy metals (e.g. Antimony, Arsenic, Chromium, Cobalt, Copper, Lead, Mercury, Nickel, Zinc). Other pollutants of concern within the tanning industry are Azodyes, cadmium compounds, and Polychlorinated Biphenyls (Mwinyihija, 2010).

Finally, slaughterhouses have been selected because red and white meat are a main agricultural product in Arab countries (Arab Organization for Agricultural DevelopmentAOAD, 2008). Moreover, red meat is considered an important staple food while the poultry sector in the Arab countries is considered one of the main sectors in the production process and provides employment for many (The Poultry Net, undated). Additionally, the poultry sector is needed to achieve food security in the relevant countries (The Poultry Net, undated; Mirzaei et al., 2005).
HESSD

10, 999-1039, 2013

\section{Virtual industrial water usage and wastewater generation}

S. R. Sakhel et al.

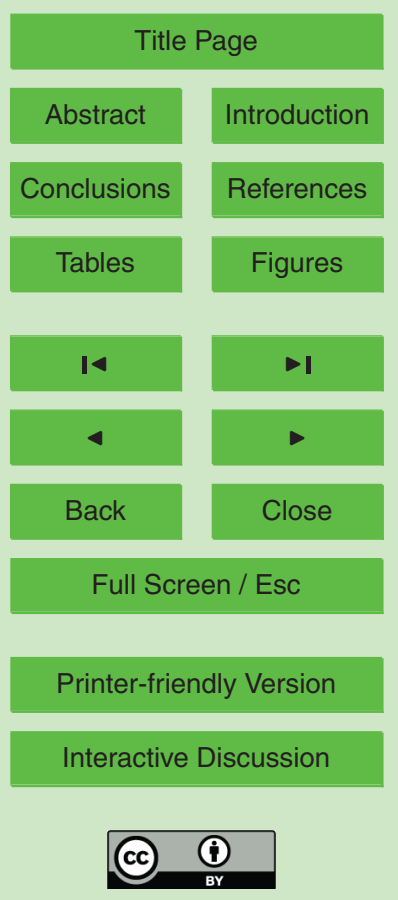


It is worthwhile to mention that specific water use or wastewater generation for the production of the relevant items in the different MENA countries and industries is not available. Therefore, for the eight different MENA industries studied the following methodologies and assumptions have been used in order to estimate the volumes of 5 water used, wastewater generated, virtual water exported, and wastewater generated from export. These methodologies and assumptions are summarized in Table 2:

Virtual water calculations:

Crude oil: the imports in tons of EU27 from the relevant MENA countries have been taken from UN comtrade database and converted to their equivalent in barrels per year 10 input to the desalter. The water required and wastewater generated for the production of crude oil exported have been calculated based on the methodology and assumptions mentioned previously. This will give the virtual water exported and wastewater generated from export.

Refineries: EU27 imports of different kinds of refined petroleum products in tons 15 have been converted to their equivalent bbl day ${ }^{-1}$ of refined petroleum products and afterwards to their equivalent of crude oil in bblday ${ }^{-1}$ input to the crude unit of the refinery based on that every 42 gallons of crude oil makes 44.2 gallons of refined petroleum products. The refined petroleum products have been converted from tons to bbl day ${ }^{-1}$, in order to be able to use the relationship that every 42 gallons of crude oil give 44.2 gallons of refined products through multiplying the ratio (42/44.2) by the refined petroleum products in bbl day ${ }^{-1}$.

From the quantity of crude oil input to the crude unit the water required for the production of these refined products has been calculated and therefore the virtual water exported is quantified. The wastewater generated from export has been calculated based on calculating an average wastewater generated figure for the refineries in each relevant country in $\left(\mathrm{m}^{3} \mathrm{yr}^{-1}\right)$ per (bbl of crude oil input to the crude unit day ${ }^{-1}$ ).

Nitrogenous fertilizers: EU27 import of urea, ammonium sulphate (no import was present for the year 2001 from MENA), ammonium nitrate, and calcium ammonium nitrate from the relevant MENA countries in tons have been used for calculating the
HESSD

10, 999-1039, 2013

\section{Virtual industrial water usage and wastewater generation}

S. R. Sakhel et al.

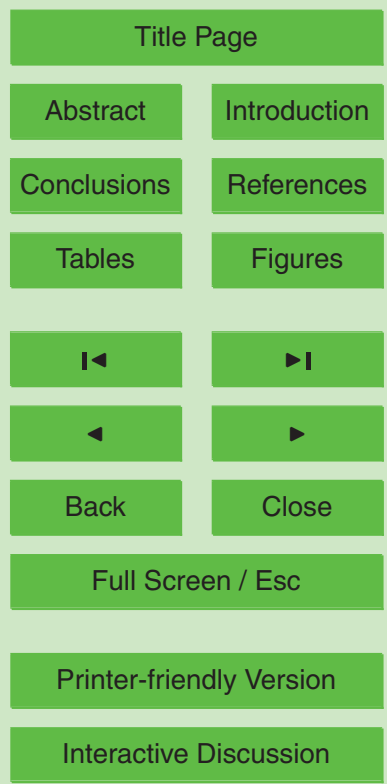


water required and the wastewater generated from their production according to the methodology and assumptions mentioned previously. This will give the virtual water exported and the wastewater generated from export of these four fertilizers.

Phosphatic fertilizers: EU27 imports of SSP and TSP in tons have been used for 5 calculating the water required and the wastewater generated from their production according to the methodology and assumptions mentioned previously. This will give the virtual water exported and the wastewater generated from export of these two fertilizers.

Pig iron, potash, olive oil, and slaughterhouses: EU27 import of pig iron, potash, olive 10 oil, different kinds of meat and edible meat offal in tons have been used for calculating the water required and wastewater generated for the production of the aforementioned commodities according to the methodology and assumptions mentioned previously. This will give the virtual water exported and wastewater generated from export of pig iron, potash, olive oil, meat and edible meat offal.

15 Leather: EU27 imports of different kinds of leather in tons from MENA have been converted to their equivalent of raw hide input to the tanneries. The water required and wastewater generated for the production of the different kinds of leather exported have been calculated based on the methodology and assumptions mentioned previously. This will give the virtual water exported and wastewater generated from export.

\section{Results}

\subsection{Water usage, and wastewater generation}

\subsubsection{Crude oil industry}

MENA countries produce $36.3 \%$ of the total world crude oil while EU27 produces $3.5 \%$, and the rest of the world $60.2 \%$ (extracted from US Energy Information Administration (USEIA)). Table 3 shows the crude oil industry water usage, water availability,

\section{HESSD}

10, 999-1039, 2013

\section{Virtual industrial water usage and wastewater generation}

S. R. Sakhel et al.

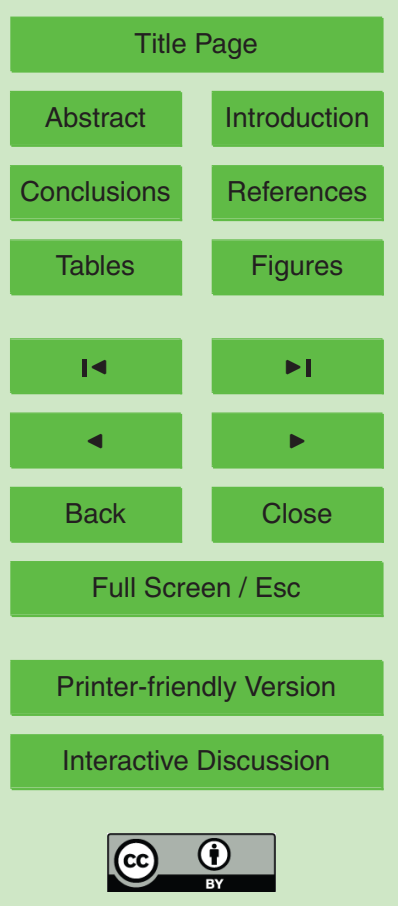


and domestic water withdrawal in $\mathrm{km}^{3} \mathrm{yr}^{-1}$ for 11 MENA producing and exporting countries. The export is based on EU27 import from MENA countries taken from UN comtrade database for the year 2001. It is obvious that Saudi Arabia is the largest water user which contributes to $42 \%$ of the domestic water withdrawal in this country. The 5 crude oil water usage in relation to domestic water withdrawal ranges between 0.7 to $89 \%$. Remarkably, the Kuwaiti crude oil water use is $89 \%$ of the total domestic water withdrawal.

\subsubsection{All selected industries}

The total annual estimated volumes of water required for the eight industries studied 10 along with the water availability and domestic water withdrawal in MENA are summarized in Table 4. Saudi Arabia has the highest water requirement, which is mainly due to the crude oil and refining industry sector. The annual estimated total water required for the exporting industries in MENA countries is about $3.4 \mathrm{Gm}^{3}$. As an illustration, the total water withdrawal for the year 2000 in MENA for agriculture and domestic purposes is 232 , and $20.3 \mathrm{Gm}^{3}$, respectively (FAOA2005). Kuwait is a unique case as the exporting industries consume more water (137\%) than that required for domestic purposes. Moreover, Table 4 shows that the water availability in 11 MENA countries is negative as their water withdrawal is larger than the renewable water resources. The crude oil and refining industry sector represents $76.7 \%$ of the total water required for the eight exporting industries, and is followed by the fertilizer sector with $18.7 \%$ and the meat sector with $3.6 \%$. Next, Table 5 shows the annual wastewater volumes of the eight export relevant industries which range between 0.7 to $272 \mathrm{Mm}^{3}$ (in Middle East countries the rate of daily wastewater generation per person ranges between 80 to $200 \mathrm{~L}$ (BioEnergy Consult Blog, undated). The average of this range ( $140 \mathrm{~L}$ per person per day) was taken to calculate the population equivalent in terms of wastewater quantity) which is equivalent to a population from about 13700 to 5.3 million in terms of wastewater quantity. The wastewater volumes of the selected industries represent
HESSD

10, 999-1039, 2013

\section{Virtual industrial water usage and wastewater generation}

S. R. Sakhel et al.

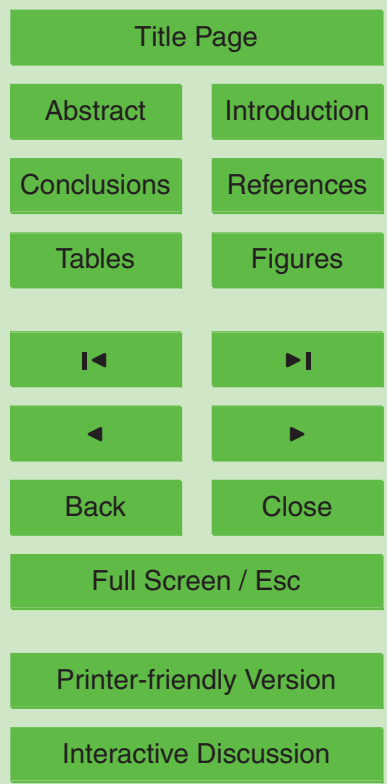


a population equivalent of about 15.5 million in terms of wastewater quantity which is $4.9 \%$ of the total population in MENA countries (317 million people, 2001). Only a very limited amount of data from literature was available which has been summarized and compared with our own data in Table 6 . The calculated water usage and wastewater 5 generated is in general in good accordance with the published data; this demonstrates that the methodology and the related assumptions are appropriately defined.

\subsection{Virtual water export and wastewater generated from export}

\subsubsection{Crude oil}

The estimated volumes of virtual water exported and the wastewater volumes generated from export of crude oil to EU27 for the year 2001 are summarized in Table 7 . The wastewater generated from export represents $16.5 \%$ of the total wastewater generated from crude oil production within eleven MENA countries. Saudi Arabia and Libya, as the main crude oil exporting countries, produce the largest volumes of virtual water and wastewater. However, the strongest influence of virtual water export is taking place in 15 Libya where it accounts for $11 \%$ of the municipal water withdrawal whereas the mean value for all eleven countries is as low as $1.7 \%$.

\subsubsection{All selected industries}

The indirect pressure that EU27 imposes on the water resources of the MENA countries and the region as a whole is summarized in Table 8. Libya and Saudi Arabia are the largest virtual water exporters, which is mainly due to the export of crude oil and refined petroleum products (see Table 8 ). The virtual water export for MENA countries ranges from 0 to $87 \mathrm{Mm}^{3}$, and about $409 \mathrm{Mm}^{3}$ for the whole region. This is sufficient to satisfy the water demand of about 7.5 million people (total MENA population in 2001: 317 million people). The export of crude oil and refined petroleum products represent about $89 \%$ of virtual water export from this region, followed by phosphatic/nitrogenous
HESSD

10, 999-1039, 2013

Virtual industrial water usage and wastewater generation

S. R. Sakhel et al.

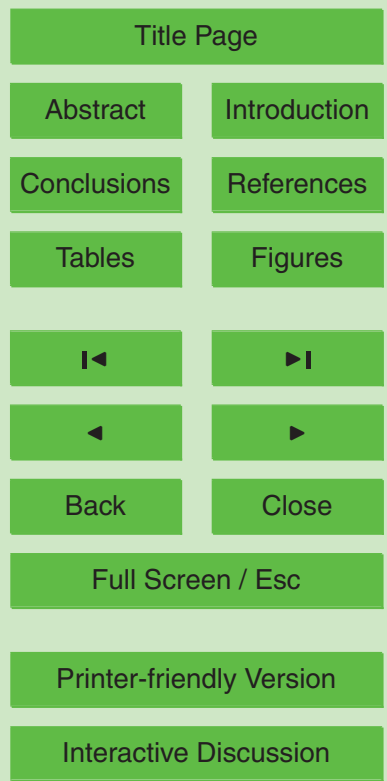


fertilizer export which represents around $10 \%$. The greatest impact can be identified on the Kuwaiti hydrological system, where the virtual water export represents around $96 \%$ of the actual renewable water resources. The influence in Libya is noticeable (14.5\%), but in the other countries much smaller. However, the overall water demand of industry 5 in Kuwait, UAE, Saudi Arabia, Qatar, Bahrain and Libya contributes from $28 \%$ up to $1364 \%$ of the total actual renewable water resources, which emphasizes the extreme pressure of the industry on the local water supply.

\section{Pollution and indirect pollution}

The pollution load of the studied industries due to production and export has been esti10 mated in terms of the Biological Oxygen Demand (BOD), and is shown in Tables 9 and 10 , respectively. It can be seen that the highest pollution load results from the crude oil industry. The pollution from the production of slaughterhouses is at second place while it is a negligible indirect polluter due to the low export rate. The total pollution load is equal to 30.4 million population equivalents (the population equivalent is calculated 15 based on an estimated value in Africa and Middle East of 37 and $40 \mathrm{~g}$ of BOD generated per person per day, respectively (IPCC Guidelines for National Greenhouse Gas Inventories, 1994)). Due to its large export quantities (for the year $2001 \mathrm{EU} 27$ imported $86811 \mathrm{t}$ of olive oil from Israel, Lebanon, Morocco and Tunisia), olive oil mills are the second strongest indirect polluter after crude oil. The overall load resulting from export

\section{Discussion}

\subsection{Water and virtual water}

The virtual water flow calculated in this study from MENA to EU27 quantifies the relation between consumption of goods and the water used for production. This paper is

HESSD

10, 999-1039, 2013

\section{Virtual industrial water usage and wastewater generation}

S. R. Sakhel et al.

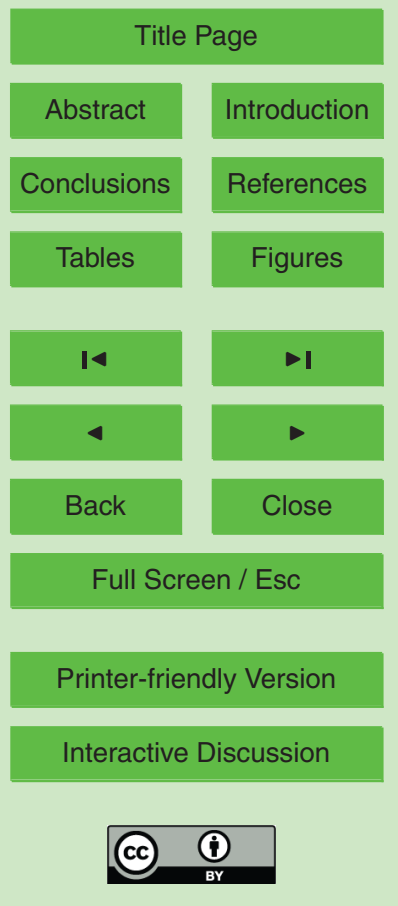


focused to estimate the water requirements and wastewater generation for eight export relevant industries. The goal was to select important industries that export goods to EU27 and to quantify/evaluate the indirect pressure that EU27 poses on the MENA hydrological system. However, there are countries within this region whose local water 5 resources are under extremely high pressure. This is an incentive for investigating also non-export relevant industries (this is based on UN comtrade database in which imports of EU27 from a specific MENA country and industry in 2001 was not present (for refined petroleum products and phosphatic fertilizers this was for the year 1999 and 2010, respectively)). For example, Saudi Arabia is a country which has an extremely 10 high pressure on its local water resources. This is obvious from its water availability that is smallest among MENA countries $\left(-15 \mathrm{~km}^{3} \mathrm{yr}^{-1}\right)$. Therefore, investigating other important non-exporting industries in this water impoverished country, by estimating the water requirements and wastewater generation, is indeed a step in the right direction. The fertilizer industry is such a non-exporting industry which is controlled by 5 companies such as Saudi Basic Industries Co. (SABIC) and Saudi Arabian Fertilizers Company (SAFCO) that have sales of 40.62 and 0.94 billion US $\$$ for the year 2009 (Forbes, 2009), and have 32000 and 990 employees (GulfBase, undated), respectively. Therefore, they are classified as large-sized companies. High polluting industries are also worth investigating in Saudi Arabia (e.g. tanneries). In fact, the eight non-export relevant industries in these countries should be considered in order to have a complete picture of the pressure that these industries have on the local water resources. Oman's crude oil industry has not been considered at all in this work although it is an important industry in this Sultanate whose production is controlled by several companies. Petroleum Development Oman (PDO) produces more than $90 \%$ of the crude oil in this country and this company is classified as a large-sized Enterprise according to European criteria. PDO has 4,211 employees (2009) and a revenue of 7.4 billion US \$ (DinarStandard, 2010).

The industry that is most relevant in terms of water demand within MENA countries is that of crude oil. As shown previously, the estimated crude oil industry water
HESSD

10, 999-1039, 2013

\section{Virtual industrial water usage and wastewater generation}

S. R. Sakhel et al.

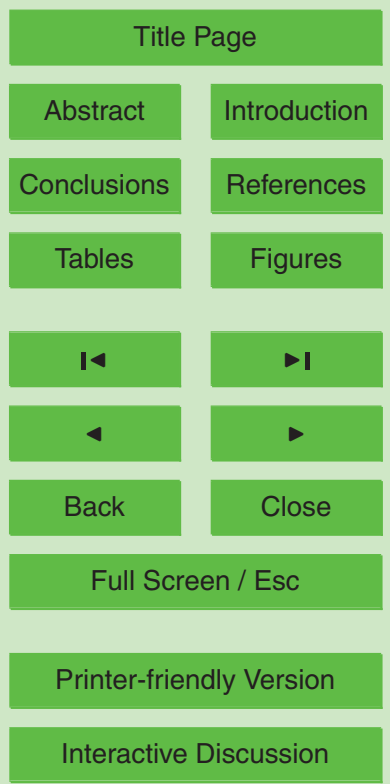


usage is about $1.81 \mathrm{~km}^{3}$. No literature data is available to compare this estimate. At present, it is common practice in large parts of North Africa to use freshwater from the regionally extensive Cretaceous aquifer as injection water for oil reservoir pressure maintenance (Hardisty, 2010). Libya repressurises its oil wells using freshwater 5 from Nubian sandstone and analogous aquifers, and it is estimated that this withdrawal exceeds $75 \mathrm{Mm}^{3}$ (Hardisty, 2010). Also countries in the Middle East use water for pressure maintenance. For example, the largest oil field in Saudi Arabia (Al-Ghawar) uses about 406 million $\mathrm{m}^{3}$ of water annually for pressure maintenance (Durham, 2005). This means that in the previously mentioned two countries more than $481 \mathrm{Mm}^{3}$ of water is 10 used per year for injection. Al Furat Petroleum Company of Syria uses also water from the Euphrates River in addition to the produced water to maintain the pressure of the oil wells controlled by this large sized company (Al Furat Petroleum Company website, undated).

Indirect water use by EU27 comes mainly from the import of crude oil, refined 15 petroleum products and fertilizer goods. The industries that produce these goods are the most relevant since about $99 \%$ of the total indirect water use comes from these three major industries. This main finding is based on estimations based on many statistical data. It must be emphasized that many of the pervious statistical data have been taken from integrated pollution, prevention, and control European documents. In this case, it is assumed that the production efficiency in terms of water and pollution is similar to European countries. Figure 1 shows the virtual water flows from four MENA countries to five EU27 countries. Saudi Arabia and Libya are the largest virtual water exporters in the form of crude oil and Morocco/Tunisia are the largest virtual water exporters in the form of phosphatic fertilizers.

\subsection{Pollution}

Another subject of importance is the pollution that the relevant eight industries pose on the environment. Therefore, the pollution in terms of BOD loadings resulting from
HESSD

10, 999-1039, 2013

\section{Virtual industrial water usage and wastewater generation}

S. R. Sakhel et al.

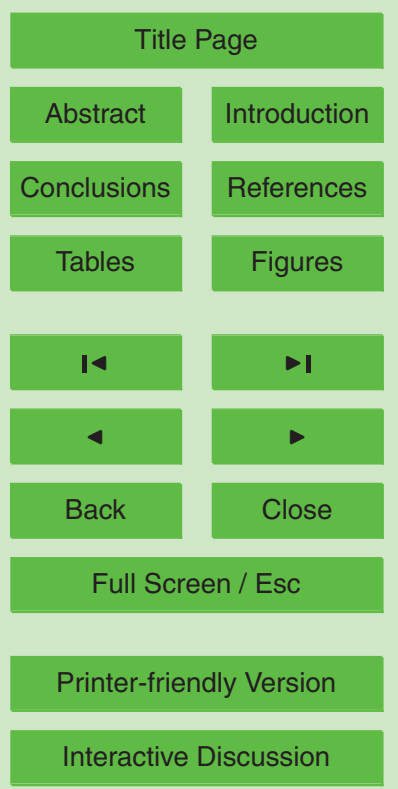


production and export, the characteristics, the effect of some of the liquid emissions, and the practices in dealing with these emissions in some MENA countries will be highlighted. As for the pollution due to production in terms of BOD within the relevant countries, the highest polluter is the crude oil industry followed by slaughterhouses.

5 The BOD emissions from export and production represent a population equivalent of about 3.7 and 30.4 million people in terms of BOD, respectively (317 million people in MENA in 2001). The ratio of $B O D_{\text {export }} / \mathrm{BOD}_{\text {production }}$ ranges between 0 to $75 \%$; with the leather industry having the highest percentage $(73.7 \%)$ and the slaughterhouses the lowest $(0.1 \%)$. The pollution of water bodies due to production is very relevant for 10 crude oil, slaughterhouses, refineries, olive oil, and tanneries but could be considered negligible for potash and pig iron industries (see Table 9). Indirect pollution is very relevant for crude oil and olive oil industries; the annual combined (crude oil and olive oil) BOD loadings represent $82 \%$ of the total from the export of all goods (see Table 10). This main finding is also based on estimations. The latter depended on typical 15 BOD values either in ppm or $\mathrm{kg} \mathrm{BOD}$ per ton of raw material or product, which resulted in the values of Tables 9 and 10 .

Liquid emissions of four industries have been selected to be highlighted, which are crude oil, petroleum refineries, olive oil, and slaughterhouses. The reason for selecting crude oil and petroleum refineries is because of their economic importance (major industries), while olive oil mills and slaughterhouses have been selected due to their high pollution potential. Additionally, the estimations of BOD loadings from production showed that these four industries are the first four ranked in Table 9. Liquid effluents from the crude oil, petroleum refineries, olive mill, and slaughterhouse industries have their own characteristics. There is the crude oil production effluent that contains a complex mixture of inorganic (dissolved salts, trace metals, suspended particles) and organic (dispersed and dissolved hydrocarbons, organic acids) compounds (Anonymous (1), undated), the highly containing toxic derivatives effluent from refineries, which contains oil and grease, phenols, sulphides, cyanides, suspended solids, nitrogen compounds as well as heavy metals such as iron, copper, selenium, zinc, molybdenum,

HESSD

10, 999-1039, 2013

\section{Virtual industrial water usage and wastewater generation}

S. R. Sakhel et al.

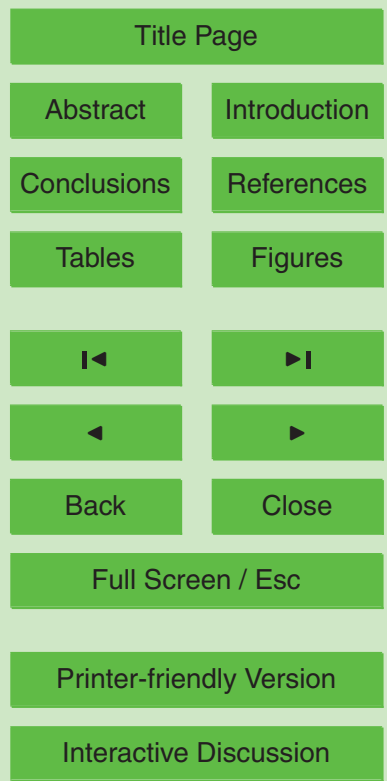

1012 
etc. (Nwanyanwu and Abu, 2010), the acidic dark colored effluents from olive oil mills that contain phytotoxic and biotoxic substances (Niaounakis and Halvadakis, 2006), and the odorous highly concentrated effluents from slaughterhouses containing additionally large amounts of nitrogen. BOD values in these industry's wastewaters can 5 be as low as $50 \mathrm{ppm}$ (crude oil industry) and can reach up to $100000 \mathrm{ppm}$ (olive mill wastewater).

The produced water from crude oil production could contain BOD values ranging from 50-1400 ppm in which oil and grease are the main pollutants of concern (Wang et al., 2004). The discharge of produced water had its effect on wetland vegetation.

10 Emergent marsh plants such as smooth cordgrass and gulf cordgrass are easily killed, even by small volume or intermittent discharges (Roach, undated). These "burned" marsh areas are the result of sodium accumulation in soils and may take years to revegetate (Roach, undated). Produced water effects on unvegetated areas are not as apparent, but possibly as severe. It was reported that the release of produced water into 15 water bodies resulted in (1) increase in the salinity of the water body thus affecting Nekton movement (2) incorporation of oil and chlorides into sediments near the discharge point thereby severely depressing the abundance and richness of benthic infauna, and (3) ingestion and incorporation of petroleum hydrocarbons into the tissues of various aquatic organisms (Roach, undated).

Refineries generate polluted wastewater that contains BOD levels of approximately 150-250 ppm (Pollution prevention and abatement handbook, World Bank Group, 1998). The ineffectiveness of refinery wastewater treatment causes these effluents to become dangerous, leading to the accumulation of toxic compounds in the receiving water bodies with potentially serious consequences on the ecosystem (Nwanyanwu and Abu, 2010). This is most probably the case for the refineries in MENA region. For example, Homs refinery wastewater in Syria is only subjected to simple physical treatment (separation of floating oil) before discharging it into the Orontes River (The Arabic Network for Human Rights Information, 2007). The wastewater from each of the three refineries in Kuwait is treated (no information about the method of treatment) before

\section{HESSD}

10, 999-1039, 2013

\section{Virtual industrial water usage and wastewater generation}

S. R. Sakhel et al.

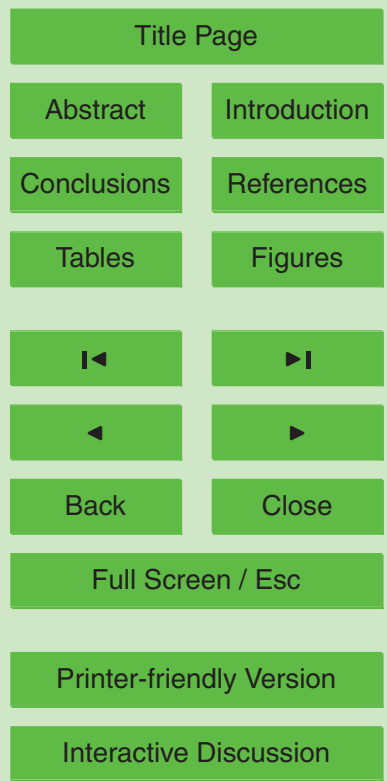


discharging it into the Arabian Gulf (Kuwait National Petroleum Company (KNPC) Annual report, 2006-2007). Oil and grease is the most critical parameter observed in Kuwait's refinery liquid emissions (KNPC Annual report, 2006-2007). It was reported (Rajesh et al., 2009) that applying oil refinery effluent for a prolonged period on a cer5 tain type of soil causes an increase in its heavy metal content ( $\mathrm{Zn}, \mathrm{Fe}, \mathrm{Cu}, \mathrm{Mn}, \mathrm{Cr}, \mathrm{Pb}$ and $\mathrm{Ni}$ ). The levels could accumulate to toxic levels, which could turn the soil to phytotoxic (Rajesh et al., 2009). This should be a caution to the countries that use refinery wastewater for irrigation as is the case in Jordan (Mohsen and Jaber, 2002).

The high BOD value of olive mill wastewater causes it to have high organic loads, and is classified to be among the strongest industrial effluents (Niaounakis and Halvadakis, 2006). It is reported that the pollution load of olive mill effluent is $5-10$ or even 25-80 times larger than domestic sewage (Boari et al., 1984; Schmidt et al., 2000). The BOD emissions from olive oil production have been estimated to be $22739 \mathrm{t} \mathrm{yr}^{-1}$ in the four countries (see Table 9). This represents a population equivalent of about 1.7 million people in terms of BOD (49 million people in these four countries, 2001). Most of the olive oil mill wastewater in Morocco is discharged raw without any treatment: either directly or through the public sewage system. These actions pose serious environmental problems. In Lebanon, raw olive mill wastewater is discharged to water bodies (7\% of the total), applied to land (30\% of the total), and discharged to the sewage system (27\% of the total) (Hamdan, 2009). Values for the non-biodegradable COD for olive oil mill wasterwater using different biological treatment technologies have been reported earlier by Yeşilada et al. (1999), Gonçalves et al. (2009), Ammary (2005), and Hamid et al. (1992). Yeşilada et al. (1999) used seven strains of fungi and the lowest nonbiodegradable COD value was $4.46 \mathrm{gL}^{-1}$. On the other hand, Gonçalves et al. used 25 six different yeasts and the non-biodegradable COD ranged from 53.4 to $122.6 \mathrm{gL}^{-1}$. Hamdi et al. (1992) applied three biological treatment steps in series and obtained a non-biodegradable COD of $13.64 \mathrm{gL}^{-1}$. Ammary et al. (2005) used an anaerobic sequencing batch reactor in order to obtain a non-biodegradable COD of $2.7 \mathrm{gL}^{-1}$.
HESSD

10, 999-1039, 2013

\section{Virtual industrial water usage and wastewater generation}

S. R. Sakhel et al.

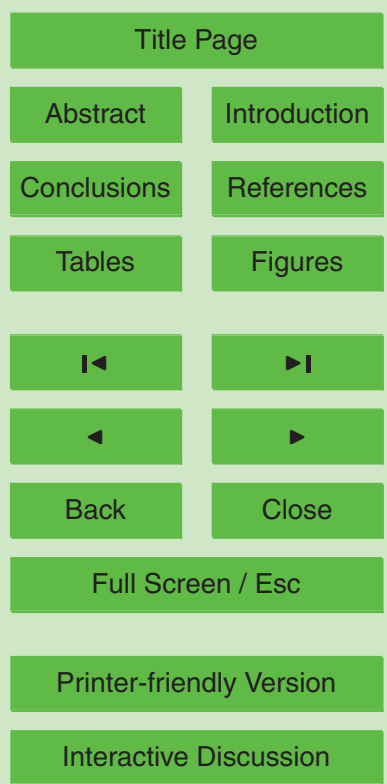


Contagious due to the possibility of containing pathogens like Salmonella and Shigella bacteria, slaughterhouses wastewater is one of the most serious causes of environmental pollution in developing countries (Kumar, undated). The BOD can reach up to 8000 ppm (Environmental Sustainability Resource Center, 2008) which is more 5 than an order of magnitude higher than untreated domestic wastewater (110-350 ppm $\mathrm{BOD}_{5}$, Anonymous (2), undated). Blood is a major contributor to the organic load of this effluent. Blood's BOD ranges from 150000-200000 ppm with extreme values being 405000 ppm (Verheijen et al., 1996). In terms of BOD and COD, abattoirs effluents have a high strength compared to domestic wastewater (Wang et al., 2006).

10 It was reported that the discharge of raw wastewater from abattoirs to the soil will have a strong pollution potential due to the contamination with pathogens (Adesemoye et al., 2006). This might affect the diversity of the soil autochthonous species eventually destroying the delicate ecological balance of the soil. Slaughterhouses in Alexandria and Fayoum governorates deal with the blood without discharging it into the 15 public sewage system or directly into the environment (Egyptian Environmental Affairs Agency (EEAA), 2007a, b). In the Alexandria governorate blood is converted to a powder and sold (EEAA, 2007a) while it is dried and sold as a fertilizer in the Fayyoum governorate (EEAA, 2007b). Gharbia and Matrouh governorates slaughterhouses do not have a system for treating blood which indicates that it is discharged with the rest of the effluent into the public sewage system or directly into the environment (EEAA, 2007c, d). However, there is no Egyptian reference describing the problem with antibiotics.

\section{Conclusions}

There is a considerable water demand and pollution potential both caused by the ex25 porting and non-exporting industries in MENA countries. The presence of virtual water flow to EU27, which is due to the flow of export commodities to EU27, increases the pressure. The MENA industries do not have the technological development that EU27

HESSD

10, 999-1039, 2013

\section{Virtual industrial water usage and wastewater generation}

S. R. Sakhel et al.

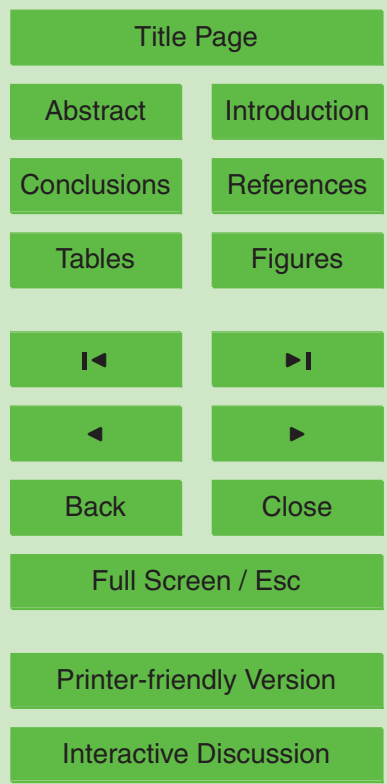


industries possess. This applies similarly to the water saving techniques. Presumably, there is a lot of water drainage in the exporting industries and no effective measures are taken to reduce it. However, EU27 and MENA should cooperate to reduce the industries water requirement. This can be achieved by supporting the implementation of the 5 latest technologies, which will lead to alleviation of the environmental impact that these industries have. This suggestion is a must because the situation of the water resources in MENA is precarious due to the population growth (2\% in MENA (P\&M) for the year 2002, Roudi-Fahimi et al., 2002), the lack of rain which causes the actual renewable water resources per capita in MENA to be several times less than in other water rich countries of the world and the climatic change. The estimations of water usage and wastewater generation have been done mainly by applying European specific water usage and wastewater generation figures. Improvement of the figures in this work can be achieved if actual specific numbers from the relevant countries are available. Therefore, the governments in these countries should oblige the firms to record their water usage and wastewater generation. It is necessary for the governments of this region to reduce the taxes paid by the firms which apply water use reduction techniques or to implement other incentives. This would be a first step to improve the sustainability of these industries. The Kuwaiti hydrological system is under the greatest pressure internally and externally (EU27 export). The pollution from these industries is worrying especially due to a presumable discharge of their wastewater directly into the environment or through the public sewage system without any or a partial treatment. This is the case for olive mill wastewater in Morocco and Lebanon, and slaughterhouses liquid emissions in Egypt. Measures should be taken to alleviate the risks from the pollution such as investing in cleaner production technologies, which has both economical and environmental benefits. This could be performed by companies having large revenues such as Saudi Aramco and National Iranian Oil Company (NIOC). Indirect water usage by EU27 is most relevant for crude oil, refineries, and fertilizers industry. Pollution of water bodies, in terms of BOD, due to production is most relevant for crude oil,
HESSD

10, 999-1039, 2013

\section{Virtual industrial water usage and wastewater generation}

S. R. Sakhel et al.

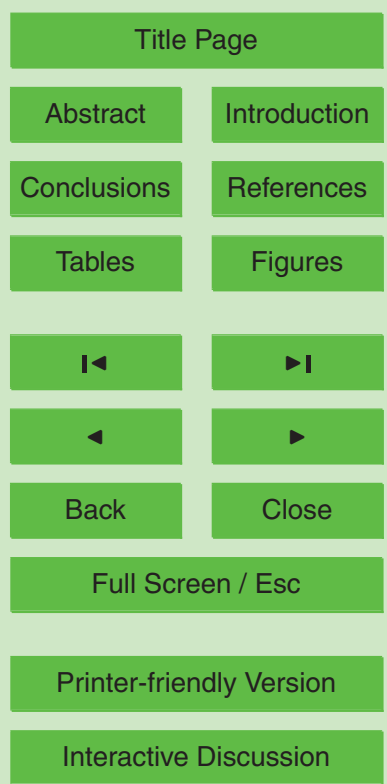


slaughterhouses, refineries, olive oil, and tanneries but pollution of water bodies by the export of goods is very relevant for crude oil industry and olive oil mills.

\section{References}

Abderrahman, W.: The International Development Research Center, http://www.idrc.ca/en/ ev-93954-201-1-DO_TOPIC.html, last access: 8 January, 2011.

Adesemoye, A. O., Opere, B. O., and Makinde, S. C. O.: "Microbial content of abattoir wastewater and its contaminated soil in Lagos, Nigeria", Afr. J. Biotechnol., 5, 1963-1968, 2006.

Alahmad, M.: A guidance on industrial water consumption in Homs refinery: when is a new refinery going to be established?, http://ouruba.alwehda.gov.sy/_archives.asp?FileName= 106894747820051107202851, 2005 (in Arabic).

Al Furat Petroleum Company website, http://www.afpc-sy.com/new/history.htm, last access: 7 March, 2011.

Al-Hakawati: http://www.al-hakawati.net/english/states/index.asp (last access: 18 January 2013), 2010.

15 Alsubuh, A.: Poultry industry in Syria ... the demand on poultry meat in Syria is still promising and developed to satisfy the needs of the domestic market, http://jamahir.alwehda.gov.sy/ _-archives.asp?FileName $=6575358120091111001821$ (last access: 19 September 2010), 2009 (in Arabic).

Allan, J. A.: Fortunately there are substitutes for water otherwise our hydro-political futures would be impossible, in: Priorities for Water Resources Allocation and Management, Overseas Development Administration, London, 13-26, 1993.

Ammary, B. Y.: Treatment of olive mill wastewater using an anaerobic sequencing batch reactor, Desalination, 177, 157-165, 2005.

Anonymous (1): Water Pollution in Petroleum Industry, http://www.slideshare.net/mechportal/ water-pollution-in-petroleum-industry, last access: 23 February, 2011.

Anonymous (2): https://dspace.ist.utl.pt/bitstream/2295/163262/1/IT_Caracterizacao_ qualitativa_aguas_residuais_2_.pdf (last access: 23 January 2013), 2010.

Arab Organization for Agricultural Development: Arab Agricultural Statistics Yearbook 28, http: //www.aoad.org/ASSY28/Default.htm (last access: 5 October 2010), 2008.
HESSD

10, 999-1039, 2013

\section{Virtual industrial water usage and wastewater generation}

S. R. Sakhel et al.

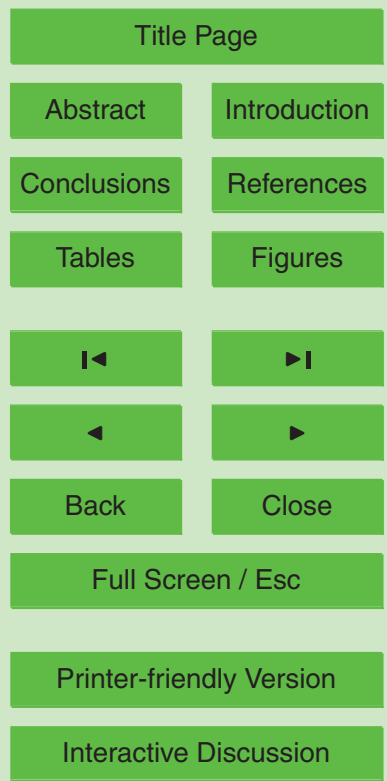


Arab steel website: Mittal Steel El-Hadjar-Increase of Sales and Decline in Production, http: //www.arabsteel.info/total/long_news_Total_e.asp?ID=116, last access: 27 January, 2011.

Asmidal company website: Statistics, http://www.asmidal-dz.com/anglais/statistics_tables.htm, last access: 23 January, 2011.

5 APC Annual Report: http://www.arabpotash.com/_potash/App_Upload/PDF/2000.pdf (last access: 18 January 2013), 2009.

Backer, L. D. and Wurtz, W. M.: Why every air cooled steam condenser needs a cooling tower, Cooling Technology Institute, 2003.

Berman, I. and Wihbey, P. M.: Institute for Advanced Strategic \& Political Studies, http://www. iasps.org/strategic/water.htm (last access: 10 January 2011), 1999.

BioEnergy Consult Blog: Powering Clean Energy Future, http://bioenergyconsult.wordpress. com/2011/09/30/biomass-feedstock-in-middle-east-and-north-africa-mena/, last access: 1 November, 2011.

Boari, G., Brunetti, A., Passino, R., and Rozzi, A.: Anaerobic digestion of olive oil mill wastewaters, Agric. Wastes, 10, 161-175, 1984.

Brigden, K. and Stringer, R.: A critical assessment of the Kishon River Masterplan Report published by the State of Israel Ministry of Environment, www.greenpeace.to/publications/ Kishon\%20Haifa\%202002.pdf, last access: 26 August 2010, 2002.

Burklin, C. E.: Revision of Emission Factors for Petroleum Refining, EPA-450/3-77-030, US Environmental Protection Agency, Research Triangle Park, NC, 1977.

Chapagain, A. K. and Hoekstra, A. Y.: Virtual water flows between nations in relation to trade in livestock and livestock products, Value of Water Research Report Series No. 13, Delft, the Netherlands: UNESCO-IHE, 2003.

Chapagain, A. K. and Hoekstra, A. Y.: Water footprints of nations, Value of Water Research Report No. 16, Delft, the Netherlands: UNESCO-IHE, 2004.

DinarStandard: Top 100 companies of the Muslim World: 2010 DS100 Ranking, http:// dinarstandard.com/rankings/top-100-companies-of-the-muslim-world-2010-ds100-ranking/ (last access: 25 February 2011), 2010.

Durham, L. S.: The Elephant of All Elephants, prepared for AAPG, http://www.aapg.org/ explorer/2005/01jan/ghawar.cfm (last access: 1 September 2010), 2005.

Da'ood, F.: Aldardari: We continue to support the poultry sector and strive that Syria becomes a center in production and manufacturing in the Middle East, http://www.sadasoria.com/

HESSD

10, 999-1039, 2013

\section{Virtual industrial water usage and wastewater generation}

S. R. Sakhel et al.

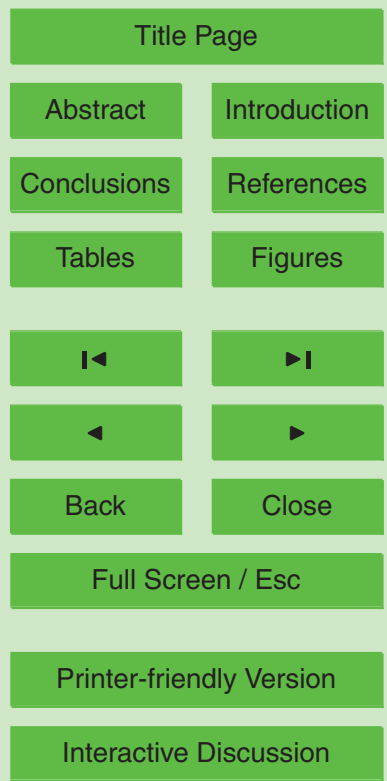


arabic/page-select-id-show_det-14-14726.htm (last access: 19 September 2010), 2009 (in Arabic).

Economy Watch: http://www.economywatch.com/world-industries/major-industry.html, last access: 8 August, 2010.

5 ECOTAN: Demonstration of clean technologies in tanning processes LIFE04 TCY/ET/000045, http://ec.europa.eu/environment/life/project/ Projects/index.cfm?fuseaction=home.createPage\&s_ref=LIFE04 $\{\%\} 20$ TCY $/$

$E T / 000045 \& a r e a=3 \& y r=2004 \&$ n_proj_id $=2809 \& \mathrm{cfid}=118813 \&$ cftoken $=$ a1120b10f25be155-A4FACFE7-CDE7-EA4F-E069E1D39CBCEE12\&mode=print\&menu= 10 false, last access: 12 September, 2010.

Egyptian Environmental Affairs Agency: Alexandria Governorate Environmental Profile, http: //www.eeaa.gov.eg/arabic/info/report_gov_profiles.asp (last access: 17 August 2010), 2007a (in Arabic).

Egyptian Environmental Affairs Agency: Fayoum Governorate Environmental Profile, http: 15 //www.eeaa.gov.eg/arabic/info/report_gov_profiles.asp (last access: 18 August 2010), 2007b (in Arabic).

Egyptian Environmental Affairs Agency: Gharbia Governorate Environmental Profile, http: //www.eeaa.gov.eg/arabic/info/report_gov_profiles.asp (last access: 18 August 2010), 2007c (in Arabic).

20 Egyptian Environmental Affairs Agency: Matrouh Governorate Environmental Profile, http: //www.eeaa.gov.eg/arabic/info/report_gov_profiles.asp (last access: 18 August 2010), 2007d (in Arabic).

Energy Intelligence: http://www.energyintel.com/documentdetail.asp?document_id=257568 (last access: 3 October 2010), 2009.

25 Environment Statistics: Jordanian Department of Statistics Publications, 2004.

Environmental Sustainability Resource Center: Environmental Impacts from Meat and Fish Processing, http://wrrc.p2pays.org/p2rx/index.cfm?page=subsection\&hub_id=449\&subsec_ id=15 (last access: 17 August 2010), 2008.

European Commission: Enterprise and Industry Publications: The new SME definition, http: //ec.europa.eu/enterprise/policies/sme/files/sme_definition/sme_user_guide_en.pdf (last access: 12 January 2011), 2005.

FAO AQUASTAT: http://www.fao.org/nr/water/aquastat/main/index.stm (last access: 18 January 2013), 2005.

\section{HESSD}

10, 999-1039, 2013

\section{Virtual industrial water usage and wastewater generation}

S. R. Sakhel et al.

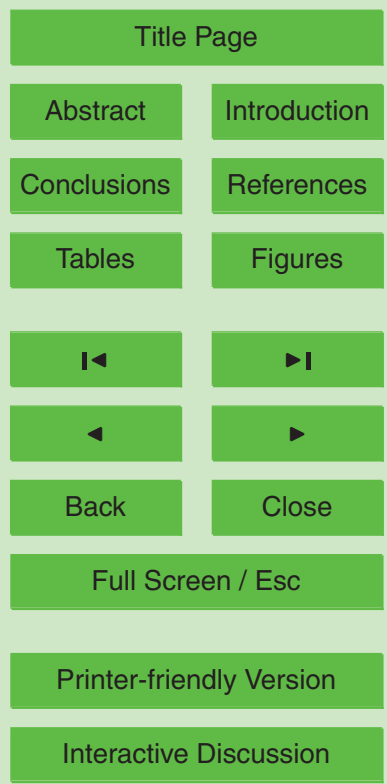


FAO AQUASTAT: http://www.fao.org/nr/water/aquastat/data/query/index.html, 2007.

Forbes: The Global 2000, http://www.forbes.com/lists/2009/18/global-09_The-Global-2000_ Counrty_11.html (last access: 28 February 2011), 2009.

Gad, A. and Ali, R.: Water rationalization in Egypt from the perspective of the virtual water con5 cept, http://ressources.ciheam.org/om/pdf/a88/00801205.pdf (last access: 7 January 2011), 2009.

Gonçalves, C., Lopes, M., Ferreira João, P., and Belo, I.: Biological treatment of olive mill wastewater by non-conventional yeasts, Bioresour. Technol., 100, 3759-3763, 2009.

GulfBase: http://www.gulfbase.com/site/interface/CompanyProfileSummary.aspx?c=202, http: //www.gulfbase.com/site/interface/CompanyProfileSummary.aspx?c=79, last access: 28 February, 2011.

Hacĕne, H., Rafa, F., Chebhouni, N., Boutaiba, S., Bhatnagar, T., Baratti, J. C., and Ollivier, B.: Biodiversity of prokaryotic microflora in El Golea Salt lake, Algerian Sahara, J. Arid Environ., 58, 273-284, 2004.

15 Hamdan, O.: Integrated Waste Management for the Olive Oil Pressing Industries in Lebanon, http://ec.europa.eu/enterprise/policies/international/files/2009_11_17_hamdan_ part1_pres_en.pdf (last access: 6 January 2010), 2009.

Hamdi, M., Garcia, J. L., and Ellouz, R.: Integrated biological process for olive mill wastewater treatment, Bioprocess. Engin., 8, 79-84, 1992.

20 Hardisty, P. E.: Environmental and Economic Sustainability, CRC Press Taylor and Francis Group, LLC, 2010.

Hoekstra, A. Y. and Hung, P. Q.: Virtual water trade: a quantification of virtual water flows between nations in relation to international crop trade. Value of Water Research Report Series No. 11. Delft, the Netherlands: UNESCO-IHE, 2002.

Integrated Pollution Prevention and Control: Best Available Techniques Reference Document on the Production of Iron and Steel, 2001a.

Integrated Pollution Prevention and Control: Reference Document on Best Available Techniques for the Tanning of Hides and Skins, 2001b.

Integrated Pollution Prevention and Control: Reference Document on best Available Techniques for Mineral Oil and Gas Refineries, 2003.

Integrated Pollution Prevention and Control: Draft Reference Document on Best Available Techniques in the Food, Drink and Milk industries, 2005.

\section{HESSD}

10, 999-1039, 2013

\section{Virtual industrial water usage and wastewater generation}

S. R. Sakhel et al.

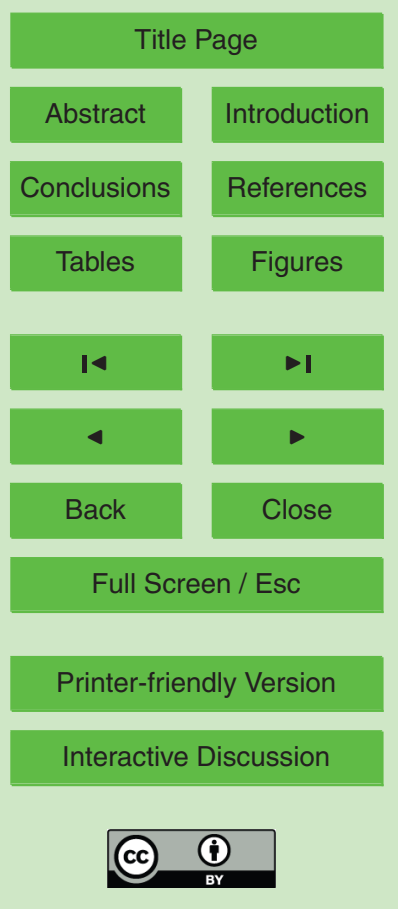


International Olive Oil Council (1): Tunisia Macroeconomic and Agricultural Indicators, http: //www.internationaloliveoil.org/modules/search (last access: 12 January 2013), 2010.

International Olive Oil Council (2): Morocco Macroeconomic and Agricultural Indicators, http: //www.internationaloliveoil.org/modules/search (last access: 18 January 2013), 2010.

5 IPCC: "IPCC Guidelines for National Greenhouse Gas Inventories, 3 Volumes: Volume 1, Reporting Instructions; Volume 2, Workbook; Volume 3, Draft Reference Manual." Intergovernmental Panel and Climatic Change, http://www.ipcc-nggip.iges.or.jp/public/gl/guidelin/ ch6ref2.pdf (last access: 2 November 2011), 1994.

Jena, H. M., Roy, G. K., and Meikap, B. C.: Comparative Study of Immobilized Cell Bioreactors for Industrial Wastewater Treatment. WMCl-2005, 1 and 2 October 2005, NIT, Rourkela, 2005.

Kamaldeep, K., Dhawan, A., and Toor, D. S.: Toxic effects of industrial effluents on hatchability and viability of Cyprinus carpio eggs, Bull. Environ. Contam. Toxicol., 50, 640-645, 1993.

Khedr, A.: Universität der Bundeswehr München Institut für Wasserwesen Mitteilungen Heft 94/2006. Socio-Economic Assessment of Water Supply in Rural Egypt (El-Gharbia Governorate, Saft Torab Case), 2006.

Kuwait National Petroleum Company (KNPC): Annual Report 2007/2008, http://www.knpc.com. kw/en/MediaCentre/Documents/part1_2007-2008.pdf (last access: 18 January 2013), 2011.

Kuwait National Petroleum Company (KNPC): Annual Report 2006/2007, http://www.knpc.com. kw/en/MediaCentre/Documents/part1_2007-2008.pdf (last access: 18 January 2013), 2011.

Kumar, M.: Waste disposal systems in slaughterhouses suitable for developing countries, FAOreport, Rome, Italy, undated.

Manning, F. S. and Thompson, R. E.: Oilfield Processing, Vol. Two: Crude Oil, Penn Well Publishing Company Tulsa, Oklahoma, 1995.

Mekki, H., Ammar, E., Anderson, M., and Ben Zina, M.: Recyclage des de'chets de latrituration des olives dans les briques de construction. "The recyling of olive oil mill byproducts in bricks", Ann. Chim. Sci. Mater., 28, 109-127, 2003 (in French).

Middle East Online: Algeria's ArcelorMittal warns strike is "illegal", http://www. middle-east-online.com/english/?id=39587 (last access: 22 January 2011), 2010.

30 Ministry of Environment-Spain: Pollution prevention opportunities in the Tanning sector industry within the Mediterranean region, www.cprac.org/docs/cur_eng.pdf (last access: 27 December 2009), 2000.
HESSD

10, 999-1039, 2013

\section{Virtual industrial water usage and wastewater generation}

S. R. Sakhel et al.

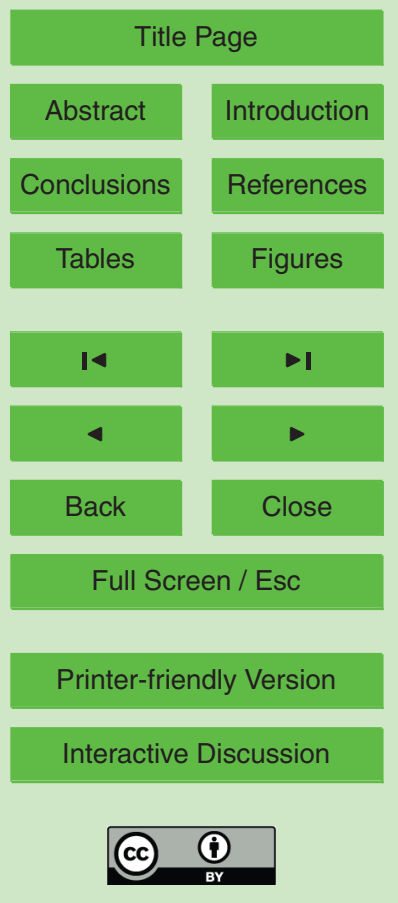


Mirzaei, F., Yazdani, S., Gharahdagh, A., and Mostafavi, M.: Iran's poultry meat export status in the Middle East region, Animal Science Research Institute of Iran, http://mpra.ub. uni-muenchen.de/5925/1/MPRA_paper_5925.pdf (last access: 3 October 2010), 2005.

Mobbs, P.: The Mineral Industry of Iran, USGS 2005 Minerals Yearbook, http://www.parstimes. com/library/mineral_industry_2005.pdf (last access: 5 January 2011), 2005.

Mohsen, M. S. and Jaber, J. O.: Potential of industrial wastewater reuse, Desalination, 152, 281-289, 2002.

Mwinyihija, M.: Ecotoxicological Diagnosis in the Tanning Industry, Springer Science + Business Media, LLC 2010, Spring Street, New York, NY 10013, USA, 2010.

10 Niaounakis, M. and Halvadakis, C. P.: Olive Processing Waste Management Literature Review and Patent Survey, Second Edition, Elsevier, United Kingdom, 2006.

Nwanyanwu, C. E. and Abu, G. O.: In vitro effects of petroleum refinery wastewater on dehydrogenase activity in marine bacterial strains, Ambi-Agua, Taubaté, 5, 21-29, 2010.

Oki, T., Sato, M., Kuwamura, A., Miyake, M., Kanae, S., and Musiake, K.: Virtual water trade to Japan and in the world, in: Virtual Water Trade, edited by: A. Y. Hoekstra, Proceedings of the International Expert Meeting on Virtual Water Trade, Value of water Research Report Series No. 12., UNESCO-IHE, Delft, The Netherlands, 221-235, 2003.

Petroleum Development Oman Annual Report (PDO): http://www.pdo.co.om/pdoweb/LinkClick. aspx?fileticket=iMp8IEfVPzl\%3d\&tabid=161\&mid=636 (last access: 25 February 2011), 2009.

Population Division of the Department of Economic and Social Affairs of the United Nations Secretariat: World Population Prospects: The 2006 Revision, Dataset on CD-ROM, United Nations, New York, 2007.

Rajesh, D., Sunil, C., Lalita, R., and Sushila, S.: Impact assessment of soils treated with refinery effluent, Eur. J. Soil Biol., 45, 459-465, 2009.

Roach, R. W.: An Assessment of Produced Water Impacts in the Galveston Bay System: Preliminary Findings, Galveston Bay Information Center, http://gbic.tamug.edu/gbeppubs/6/ gdnep6_91-96.pdf, last access: 14 February, 2011.

Rockström, J. and Gordon, L.: Assessment of green water flows to sustain major biomes of the world: implications for future ecohydrological landscape management, Phys. Chem. Earth (B), 26, 843-851, 2001.
HESSD

10, 999-1039, 2013

\section{Virtual industrial water usage and wastewater generation}

S. R. Sakhel et al.

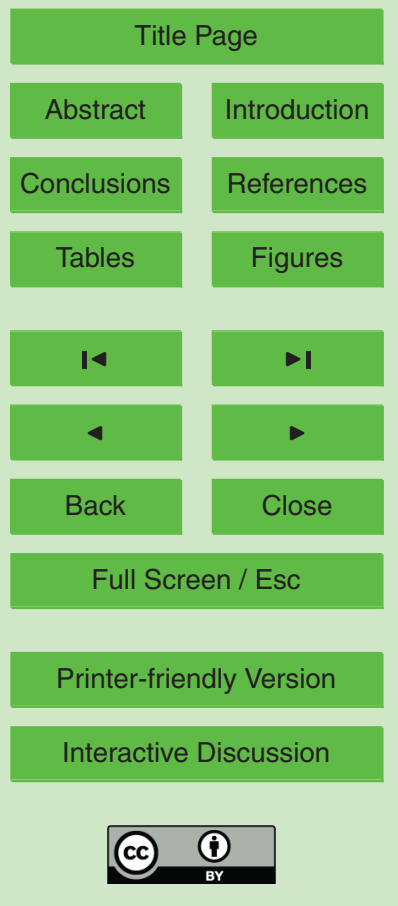


Roudi-Fahimi, F., Creel, L., and De Souza, R. M.: Population Reference Bureau, Finding the Balance: Population and Water Scarcity in the Middle East and North Africa, http://www.prb. org/pdf/FindingTheBalance_Eng.pdf (last access: 3 September 2010), 2002.

Sandy, T.: Water Reduction and Reuse in the Petroleum Industry, http://www.perf.org/pdf/sandy. pdf (last access: 20 April 2007), 2005.

Sayadi, S., Gouider, M., Feki, M., Bouzid, J., Kallal, M., Elleuch, B., Mouadhen, G., Zribi, K., Loukil, S., Bouaziz, M., Jbir, S., and Dhouib, A.: Advanced technologies for the treatment of industrial and coastal waters of the Mediterranean region, Contract No. INCO-CT-2004509159, 2008.

10 Schmidt, A., and Knobloch, M.: Olive oil-mill residues: The demonstration of an innovative system to treat wastewater and to make use of generated bioenergy and solid remainder, Proc. 1st World Conf. on Biomass for Energy and Industry, Seville, 5-9 June 2000, 452-454, 2000.

STIR company website: http://www.stir.com.tn/english/contenu.php?rub=1\&sous_rub= 4\&devise, last access: 17 January, 2011.

Taib, M.: The Mineral Industry of Jordan. USGS 2007 Minerals Yearbook, http://minerals. usgs.gov/minerals/pubs/country/2007/myb3-2007-jo.pdf (last access: 12 September 2010), 2007.

Taib, M.: The Mineral Industry of Oman USGS 2008 Mineral Yearbook, http://minerals.usgs. gov/minerals/pubs/country/2008/myb3-2008-mu.pdf (last access: 5 March 2011), 2008.

20 The Arabic Network for Human Rights Information: http://www.anhri.net/syria/cdf/2007/pr0611. shtml (last access: 18 September 2010), 2007 (in Arabic).

The Federation of Pakistan Chambers of Commerce and Industry: http://www.fpcci.com.pk/ trade-with-countries/Yemen.pdf, http://www.fpcci.com.pk/trade-with-countries/Kuwait.pdf, http://www.fpcci.com.pk/trade-with-countries/Iran.pdf, $\quad$ http://www.fpcci.com.pk/ trade-with-countries/Saudi\%20Arabia.pdf, UAE.pdf, last access: 5 January, 2011.

The Poultry Net: The situation of the poultry in the Arab world-the need for governmental assistance, http://www.thepoultry.net/Poli/1.html, last access: 17 September, 2010 (in Arabic).

UN Comtrade Database: http://comtrade.un.org/db/, last access: 2 December, 2012.

30 US Energy Information Administration (USEIF): http://www.eia.doe.gov/, last access: 2 December 2012.
HESSD

10, 999-1039, 2013

\section{Virtual industrial water usage and wastewater generation}

S. R. Sakhel et al.

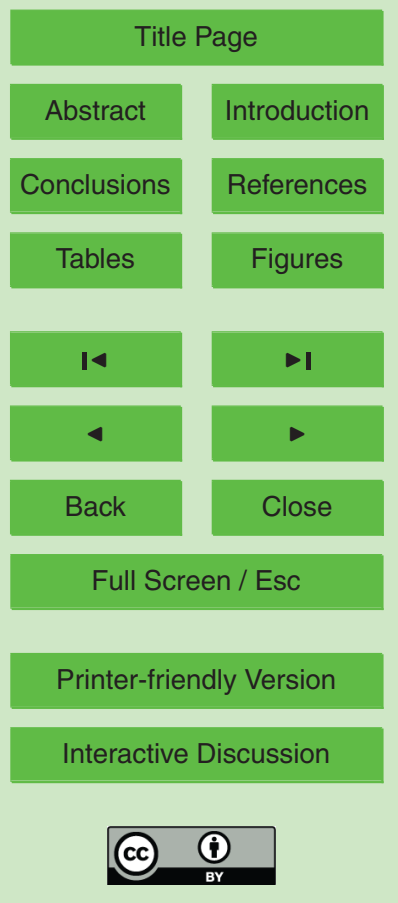


Verheijen, L. A. H.M., Wiersema, D., Hulshoff, L. W., and De Wit, J.: Management of waste from animal product processing, http://www.fao.org/docrep/004/X6114E/x6114e00.htm\#Contents (last access: 17 August 2010), 1996.

Violides-Business Development-Middle East \& North Africa: http://www.violides.com/PDF/ Violides.pdf, last access: 5 January, 2011.

Wang, L. K., Hung, Y. T., Lo, H. H., Yapijakis, C., and Hung Li, K.: Handbook of Industrial and Hazardous Wastes Treatment, 2nd Ed., Marcel Dekker Inc., New York, Basel, 2004.

Wang, L. K., Hung, Y. T., Lo, H. H., and Yapijakis, C.: Waste Treatment in the Food Processing Industry, CRC Press in an imprint of Taylor \& Francis Group, London, 2006.

Wikipedia (1): Water supply and sanitation in Jordan, http://en.wikipedia.org/wiki/Water_supply_ and_sanitation_in_Jordan, last access: 8 January, 2011.

Wikipedia (2): Saudi Aramco, http://en.wikipedia.org/wiki/Saudi_Aramco\#cite_note-0, last access: 12 January, 2011.

Wikipedia (3): National Iranian Oil Company, http://en.wikipedia.org/wiki/National_Iranian_Oil_

15 Company\{\#\}cite_note-0, last access: 13 January, 2011.

Wikipedia (4): List of Companies by Revenue, http://en.wikipedia.org/wiki/List_of_companies_ by_revenue, last access: 16 January, 2011.

Wikipedia (5): Asmidal, http://en.wikipedia.org/wiki/Asmidal, last access: 23 January, 2011.

World Bank Group: Pollution Prevention and Abatement Handbook, 1998.

20 World Resources Institute: Earthtrends, available at: http://earthtrends.wri.org/, last access: 2 December, 2012.

World statistical Compendium for raw hides and skins, leather and leather footwear 1984-2002, ftp://ftp.fao.org/docrep/fao/006/y5068T/y5068T00.pdf, last access: 24 October, 2004.

Yager, T.: The Mineral Industry of Israel, USGS 2005 Minerals Yearbook, http://minerals.usgs.

25 gov/minerals/pubs/country/2005/ismyb05.pdf (last access: 12 September 2010), 2005.

Yeşilada, Ö., Sik, Ş., and Şam, M.: Treatment of olive oil mill wastewater with fungi, Tr. J. Biology, 23, 231-240, 1999.

Zimmer, D. and Renault, D.: Virtual water in food production and global trade: review of methodological issues and preliminary results, in: Virtual Water Trade, edited by: Hoekstra, A. Y., search Report Series No. 12, UNESCO-IHE, Delft, The Netherlands, 93-109, 2003.

HESSD

10, 999-1039, 2013

\section{Virtual industrial \\ water usage and wastewater \\ generation}

S. R. Sakhel et al.

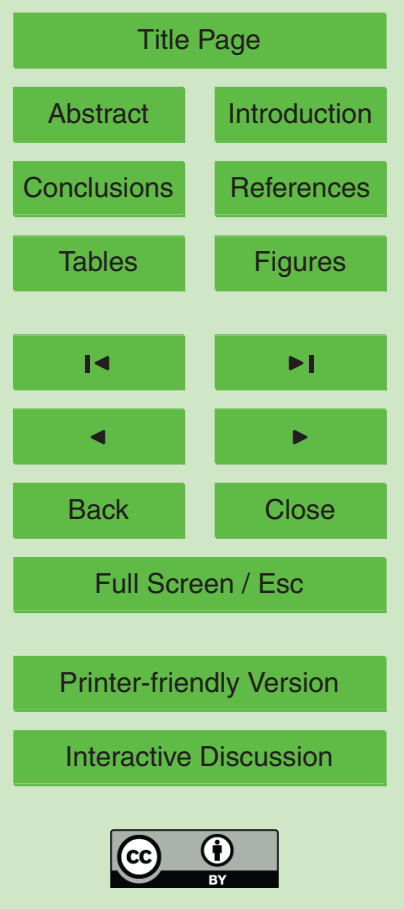




\section{HESSD}

10, 999-1039, 2013

\section{Virtual industrial water usage and wastewater generation}

1 - Wikipedia (2) (2011), 2 - Wikipedia (3) (2011), 3 - Wikipedia (4) (2011), 4 - KNPC Annual Report, 2007/2008, 5 STIR company website, 6 - APC Annual Report, 2009, 7 - Arab Steel website, 8 - Middle East Online, 2010, 9 Asmidal company website, 10 - Wikipedia (5) (2011).

\begin{tabular}{|c|c|c|c|c|}
\hline Company & Country & Industry & $\begin{array}{l}\text { Turnover in billion } \\
\text { US \$ (year) }\end{array}$ & $\begin{array}{l}\text { Staff headcount } \\
\text { (year) }\end{array}$ \\
\hline $\begin{array}{l}\text { Saudi } \\
\text { Aramco }\end{array}$ & Saudi Arabia & $\begin{array}{l}\text { Refining and } \\
\text { crude oil }\end{array}$ & $233(2008)^{1}$ & $54441(2008)^{1}$ \\
\hline NIOC & Iran & Crude oil & $78(2009)^{2}$ & 36000 (undated) ${ }^{2}$ \\
\hline Sonatrach & Algeria & $\begin{array}{l}\text { Refining and } \\
\text { crude oil }\end{array}$ & $46.4(2009)^{3}$ & $120000(2009)^{3}$ \\
\hline KNPC & Kuwait & Refining & $28.1(2008)^{4}$ & $5098(2008)^{4}$ \\
\hline STIR & Tunisia & Refining & $1.6(2009)^{5}$ & $431(2009)^{5}$ \\
\hline APC & Jordan & Potash & $0.53(2009)^{6}$ & $2195(2002)^{6}$ \\
\hline $\begin{array}{l}\text { Mittal Steel } \\
\text { El-Hadjar }\end{array}$ & Algeria & Iron and Steel & $0.51(2004)^{7}$ & $6200(2010)^{8}$ \\
\hline Asmidal & Algeria & Fertilizers & $0.19(2003)^{9}$ & $2500(2006)^{10}$ \\
\hline
\end{tabular}

Table 1. Some MENA companies with their revenues and number of staff.
S. R. Sakhel et al.

\section{Title Page}

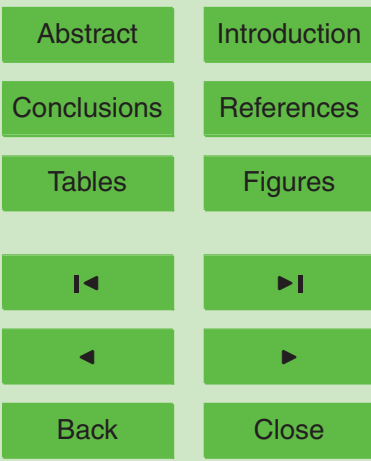

Full Screen / Esc

Printer-friendly Version

Interactive Discussion 


\section{HESSD}

10, 999-1039, 2013

\section{Virtual industrial water usage and wastewater generation}

\begin{tabular}{|c|c|}
\hline Industry & Assumptions \\
\hline \multirow[t]{3}{*}{ Crude oil } & $\begin{array}{l}\text { 1. MENA countries use water to repressurize their oil wells. } \\
\text { 2. Free water coming out with crude oil is injected into the same oil well for } \\
\text { pressure maintenance after proper treatment. } \\
\text { 3. Desalting is carried out until the volume percentage of water in crude oil is } 0.5 \% \text {. } \\
\text { 4. The entrained formation water in crude oil resulting as wastewater after desalting is } \\
\text { discharged to the environment. }\end{array}$ \\
\hline & Methodology \\
\hline & $\begin{array}{l}\text { 1. The annual volume of water to repressurize oil wells was taken equal to the yearly } \\
\text { volume of crude oil input to the desalter. } \\
\text { 2. The annual wastewater volume from the desalter is taken equal to the sum of wash } \\
\text { water plus almost all of the emulsified water in crude oil. } \\
\text { 3. The light crude oil emulsions (API }>20^{\circ} \text { ), usually the case for crude oil in MENA } \\
\text { countries (Energy Intelligence, } 2009 \text { ), have an entrained water volume ranging from } \\
\text { to } 20 \% \text { by volume (Manning and Thompson, 1995). The average of this range } \\
\text { has been taken to represent the volume percentage of formation water present in } \\
\text { MENA crude oil. }\end{array}$ \\
\hline
\end{tabular}

S. R. Sakhel et al.

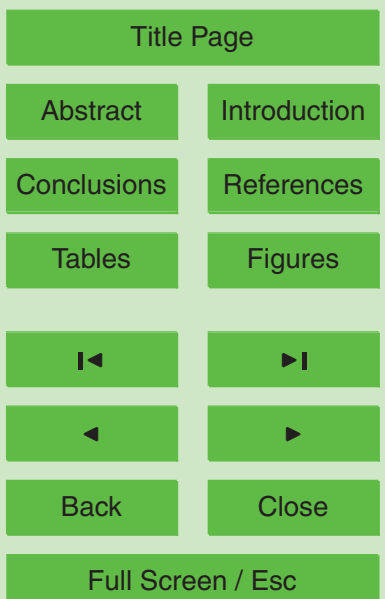

Printer-friendly Version

Interactive Discussion 
Table 2. (Continued).

Industry

Assumptions

Refineries All refineries in MENA have cooling towers (closed cooling water circulation system) with a concentration factor of 7 .

\section{Methodology}

Refineries continued

1. The annual water requirement (AWR) in the refineries of MENA countries is calculated based on average specific water requirements per barrel (bbl) $(1 \mathrm{bbl}=159 \mathrm{~L})$ of crude oil processed (Sandy, 2005).

2. The yearly wastewater volume from refineries of MENA is calculated based on the annual input to the different processing units, the blowdown of the cooling tower, plus the desalter effluent (Burklin, 1977, Integrated Pollution Prevention and Control (IPPC), 2003).

3. The AWR of the cooling towers is estimated based on the following formulas (Backer and Wurtz, 2003):

Annual cooling water requirement $=m_{\text {evap }}+m_{\text {drift }}+m_{\text {blowdown }}$,

where the evaporation rate in the cooling tower $m_{\text {evap }}$, the drift loss rate $m_{\text {drift }}$, and the blowdown rate from the cooling tower $m_{\text {blowdown }}$ are defined by:

$$
\begin{aligned}
& m_{\text {evap }}=0.00095 m_{\text {cool }}\left(T_{\text {hot }}-T_{\text {cold }}\right), \\
& m_{\text {drift }}=0.005 \% m_{\text {cool }} \text { (3) } \\
& m_{\text {blodown }}=m_{\text {evap }} /(\text { cycles }-1)
\end{aligned}
$$

In Eq. (2), $m_{\text {cool }}$ is the cooling water circulation rate in the refinery, and $T_{\text {hot }}-T_{\text {cold }}$ is the temperature drop in the cooling tower.

In Eq. (4), the cycles are the cycles of concentration in cooling tower which typically range between 3 and 10 (Backer and Wurtz, 2003).

\section{HESSD}

10, 999-1039, 2013

\section{Virtual industrial water usage and wastewater generation}

S. R. Sakhel et al.

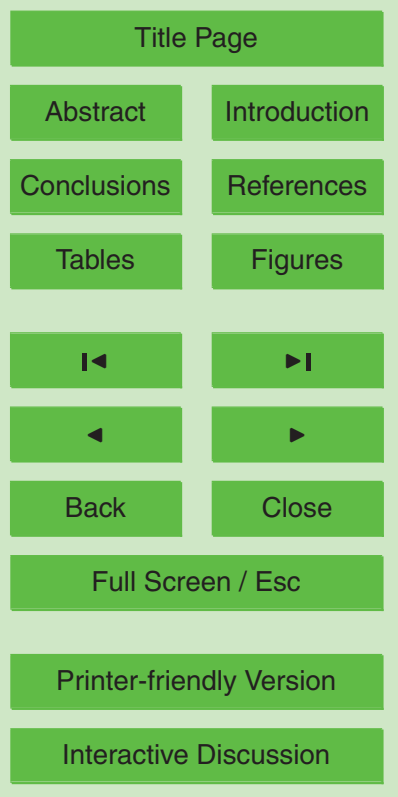


Table 2. (Continued).

\section{Industry}

Fertilizers

It is assumed that ammonia in MENA is produced by the steam

$$
\text { Methodology }
$$

1. The fertilizers considered are: Nitrogenous fertilizers (ammonia, urea, ammonium nitrate, calcium ammonium nitrate, ammonium sulfate), and phosphatic fertilizers (single superphosphate, triple superphosphate) and mixed fertilizer diammonium phosphate.

2. The AWR in Egypt's Abu Qir 1, 2, and 3 fertilizer complexes is equal to cooling tower plus boiler make-up water. Wastewater volumes are equal to cooling tower blowdowns plus estimated process condensates from urea and ammonia production.

3. The AWR for ammonia production in Algeria and Egypt's fertilizer plants (except Abu Qir 1, 2, and 3) is equal to ammonia cooling tower make-up water requirements plus part of estimated boiler make-up water requirements for $\mathrm{NH}_{3}, \mathrm{HNO}_{3}$, and ammonium nitrate production.

4. The AWR for MENA fertilizer plants (except Egypt and Algeria) producing ammonia was based on estimating the ammonia cooling tower make-up water plus part of the estimated boiler make-up water for urea and ammonia plants.

5. The annual wastewater generation (AWG) from MENA plants producing ammonia was based on estimating the volume of process condensates plus ammonia cooling tower blowdown.

6. For urea production in MENA fertilizer plants (except Abu Qir 1 and 3) AWR is the volume of make-up water requirement for urea cooling tower, part of boiler make-up water requirements for $\mathrm{NH}_{3}$, as well as urea production and water requirements for ammonia made specifically for urea production.

7. The AWG from urea production in MENA fertilizer plants (except Abu Qir 1 and 3 ) is the volume of process condensates, the volume of urea cooling tower blowdown, and the wastewater generated from production of ammonia specifically used for urea production.

Fertilizers

continued

8. For powdered or granulated single superphosphate (SSP or GSSP) production plants in MENA, the AWR is calculated based on water requirements for off-gas scrubbers, the estimated water requirements for the reaction between $\mathrm{H}_{2} \mathrm{SO}_{4}$ and phosphate rock, and the water required for phosphate rock and $\mathrm{H}_{2} \mathrm{SO}_{4}$ specifically produced for SSP production.

9. For GSSP plants, the water requirement for its production in the form of steam is also added to the previously mentioned water requirements.

10. The AWG from SSP and GSSP production is estimated based on wastewater from off gas scrubbers and from phosphate rock and $\mathrm{H}_{2} \mathrm{SO}_{4}$ specifically produced for SSP and GSSP.

11. The AWR for granulated triple superphosphate (GTSP) production is based on the water used in the form of steam, the cooling water requirements, and the off-gas scrubbers water requirements, as well as water required for producing phosphate rock, sulfuric and phosphoric acid specifically produced for GTSP production.

12. The AWG from GTSP production is the estimated cooling tower blowdown plus off-gas scrubbers wastewater, and the wastewater generated from producing phosphate rock, sulfuric and phosphoric acid specifically produced for GTSP production.

13. The AWR for ammonium nitrate (AN) or nitric acid production is part of the estimated volume of make-up water for the nitric acid and AN cooling tower plus part of the estimated volume of boiler make-up water for ammonia, nitric acid, and AN plants as well as the water requirements for ammonia and nitric acid specifically produced for AN or nitric acid production.

14. The AWG for AN or nitric acid production is part of the estimated nitric acid and AN cooling tower blowdown plus the wastewater generated from ammonia and nitric acid produced specifically for AN or nitric acid production.

\section{HESSD}

10, 999-1039, 2013

\section{Virtual industrial \\ water usage and \\ wastewater \\ generation}

S. R. Sakhel et al.

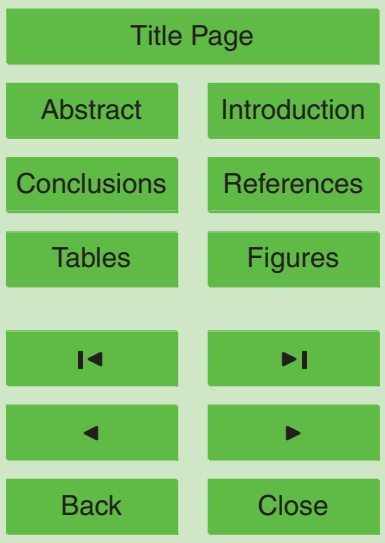

Full Screen / Esc

Printer-friendly Version

Interactive Discussion 
Table 2. (Continued).

HESSD

Pig iron 1. Raw material preparation for the blast furnace is through the sintering process.

2. Cooling towers (concentration factor 7 ) are used in the sinter plant, the coke oven, and the blast furnace, whereas the remaining water after coke quenching is discharged as wastewater.

$$
\text { Methodology }
$$

1. The AWR has been estimated based on the water requirements for sinter plant, coke oven, and blast furnace. These requirements are as follows:

(a) Sinter plant: the total amount of water required is equal to the rinsing water required for dedusting (the calculation is based on a European specific water requirement value per ton sinter (IPPC, 2001a), the water required for gas abatement (the calculation is based on a European specific water requirement value per ton sinter (IPPC, 2001a), and the make-up water for cooling tower (IPPC, 2001a).

(b) Coke oven: the total amount of water required is equal to the water required for coke quenching, and water required to compensate for evaporation losses and blowdown in indirect cooling of coke oven gas (IPPC, 2001a).

(c) Blast furnace: the total amount of water required is equal to the make-up water for both blast furnace gas cooling tower and scrubber (scrubber water make-up equals the blast furnace gas scrubbing circuit overflow and is calculated based on a European specific value per ton of pig iron (IPPC, 2001a), as well as the water required for slag granulation.

Moreover, AWG has been estimated based on wastewater generation in sinter plant, coke oven and blast furnace (IPPC, 2001a).

\begin{tabular}{lc}
\hline Industry & Assumptions \\
\hline Potash & The water used is equal to the wastewater generation. \\
\cline { 2 - 3 } & Methodology
\end{tabular}

For potash production in Israel and Jordan, AWR is estimated based on a specific average Jordanian water usage per ton potash (Personal communication, Arab Potash Company (APC), 2007).

Leather 1. The raw material of tanneries is the sum of raw hides produced in the countries of the MENA region and the net import (import-export) of raw hides.

2. All MENA tanneries process raw hides to finished leather and the wastewater volumes are equal to the water volumes used in the tannery.

\section{Methodology}

1. The AWR for leather production is the sum of water used for processing raw bovine hides, raw sheepskins/lambskins, and raw goatskins/kidskins. These raw hides and skins have been selected according to FAO's World Statistical Compendium as main types of leather produced in MENA.

2. AWR for processing the selected hides and skins is calculated based on a European average specific water requirement per ton raw input to the tannery (IPPC, 2001b). Methodology

Olive oil 1. The AWR for MENA olive oil production has been calculated on the basis of a European specific water requirements value per ton of olive oil product (IPPC, 2005).

2. AWG from olive oil production has been calculated on the basis of taking the average of European specific wastewater generation values for the three technologies used, which are: traditional, threephase extraction, and two-phase extraction (IPPC, 2005).

3. Only countries exporting larger than 10 tons of olive oil are considered.

\section{Virtual industrial \\ water usage and wastewater generation}

S. R. Sakhel et al.

\section{Title Page}

\section{Abstract}

Introduction

Conclusions

References

Tables

Figures

14

Back

Close

Full Screen / Esc

Printer-friendly Version

Interactive Discussion 


\section{HESSD}

10, 999-1039, 2013

\section{Virtual industrial water usage and wastewater generation}

Table 2. (Continued).

\begin{tabular}{ll}
\hline Industry & \multicolumn{1}{c}{ Assumptions } \\
\hline $\begin{array}{l}\text { Slaughterhouses } \\
\text { (abattoirs) }\end{array}$ & $\begin{array}{l}\text { AWG is equal to the volume of water used, and goat slaughter has the } \\
\text { same specific water usage per ton of carcass as the sheep slaughter. }\end{array}$ \\
\cline { 2 - 3 } & \multicolumn{1}{c}{ Methodology } \\
\cline { 2 - 3 } 1. $\quad \begin{array}{l}\text { The AWR for meat production has been calculated based on av- } \\
\text { erage slaughterhouses specific current water use benchmarks } \\
\text { per ton of carcass. This AWR belongs to three types of meat: } \\
\text { poultry, cattle, and sheep. These types of meat, in addition to goat } \\
\text { meat, have been selected because, according to FAO database, } \\
\text { they represent } 90 \text { to 100 \% of the total quantity of meat produced } \\
\text { during 2001 in the meat producing and exporting MENA coun- } \\
\text { tries. } \\
\text { Only countries exporting larger than 10t of meat are considered. }\end{array}$ \\
2.
\end{tabular}

S. R. Sakhel et al.

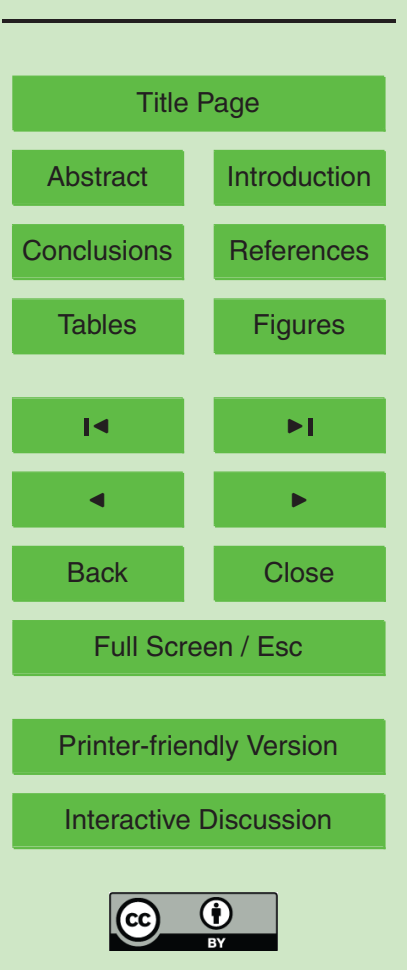




\section{HESSD}

10, 999-1039, 2013

Table 3. Crude oil industry water use, water availability, and domestic water withdrawal in $\mathrm{km}^{3} \mathrm{yr}^{-1}$ for 11 MENA countries.

\begin{tabular}{lcccc}
\hline Country & $\begin{array}{c}\text { Crude oil water } \\
\text { use }\left(\mathrm{km}^{3} \mathrm{yr}^{-1}\right)\end{array}$ & $\begin{array}{c}\text { Water availability } \\
\left(\mathrm{km}^{3} \mathrm{yr}^{-1}\right)^{1}\end{array}$ & $\begin{array}{c}\text { Domestic water } \\
\text { withdrawal } \\
\left(\mathrm{km}^{3} \mathrm{yr}^{-1}\right)^{1}\end{array}$ & $\begin{array}{c}\text { Crude oil water } \\
\text { use/domestic water } \\
\text { withdrawal }(\%)\end{array}$ \\
\hline Saudi Arabia & 0.734 & -14.9 & 1.73 & 42.4 \\
Iran & 0.269 & 64.6 & 5.10 & 5.3 \\
Kuwait & 0.178 & -0.4 & 0.20 & 89.0 \\
UAE & 0.171 & -2.1 & 0.53 & 32.2 \\
Iraq & 0.137 & 32.7 & 1.28 & 10.7 \\
Libya & 0.123 & -3.7 & 0.60 & 20.5 \\
Algeria & 0.094 & 8.2 & 1.34 & 7.0 \\
Egypt & 0.040 & -10.0 & 5.46 & 0.7 \\
Syria & 0.032 & 6.4 & 0.60 & 5.3 \\
Yemen & 0.028 & -2.5 & 0.27 & 10.5 \\
Tunisia & 0.005 & 2.0 & 0.37 & 1.2 \\
\hline Total & 1.811 & 80.2 & 17.48 & 10.3 \\
\hline
\end{tabular}

${ }^{1}$ Source: extracted or taken from FAOA2005 and FAOA2007.

\section{Virtual industrial water usage and wastewater generation}

S. R. Sakhel et al.

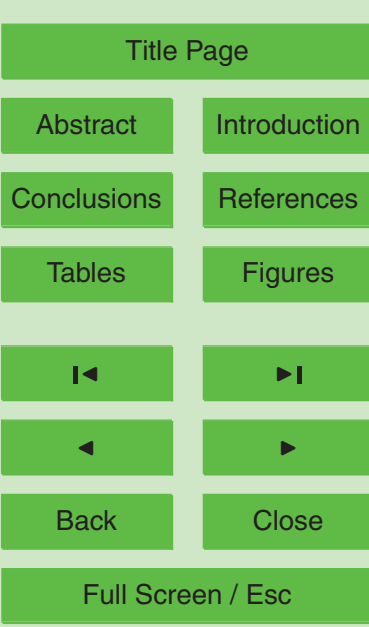

Printer-friendly Version

Interactive Discussion 
Table 4. Total water required by the eight exporting industries, water availability and domestic water withdrawal.

\begin{tabular}{lcccc}
\hline Country & $\begin{array}{c}\text { Volume of water } \\
\text { required }\left(\mathrm{km}^{3} \mathrm{yr}^{-1}\right)\end{array}$ & $\begin{array}{c}\text { Water } \\
\text { availability } \\
\left(\mathrm{km}^{3} \mathrm{yr}^{-1}\right)\end{array}$ & $\begin{array}{c}\text { Domestic water } \\
\text { withdrawal in } \\
\left(\mathrm{km}^{3}\right) \text { for the } \\
\text { year 2000 }\end{array}$ & $\begin{array}{c}\text { Water } \\
\text { required/domestic } \\
\text { water withdrawal } \\
(\%)\end{array}$ \\
\hline Saudi Arabia & 0.943 & -15.0 & 1.73 & 54.3 \\
Iran & 0.451 & 64.6 & 5.10 & 8.8 \\
Morocco & 0.333 & 16.4 & 1.26 & 26.3 \\
Kuwait & 0.273 & -0.4 & 0.20 & 137.4 \\
UAE & 0.226 & -2.1 & 0.53 & 42.5 \\
Tunisia & 0.219 & 2.0 & 0.37 & 59.0 \\
Egypt & 0.186 & -10.0 & 5.46 & 3.4 \\
Libya & 0.166 & -3.7 & 0.60 & 27.6 \\
Algeria & 0.154 & 8.2 & 1.34 & 11.5 \\
Iraq & 0.137 & 32.7 & 1.28 & 10.7 \\
Israel & 0.083 & -0.4 & 0.64 & 12.9 \\
Syria & 0.062 & 6.4 & 0.60 & 10.2 \\
Yemen & 0.042 & -2.5 & 0.27 & 15.8 \\
Qatar & 0.034 & -0.2 & 0.07 & 48.9 \\
Bahrain & 0.030 & -0.2 & 0.12 & 25.3 \\
Lebanon & 0.018 & 3.0 & 0.46 & 3.7 \\
Jordan & 0.018 & -0.1 & 0.21 & 8.5 \\
Oman & 0.009 & -0.4 & 0.10 & 9.5 \\
\hline Total & 3.383 & 98.4 & 20.33 & 16.6 \\
\hline
\end{tabular}

HESSD

10, 999-1039, 2013

\section{Virtual industrial water usage and wastewater generation}

S. R. Sakhel et al.

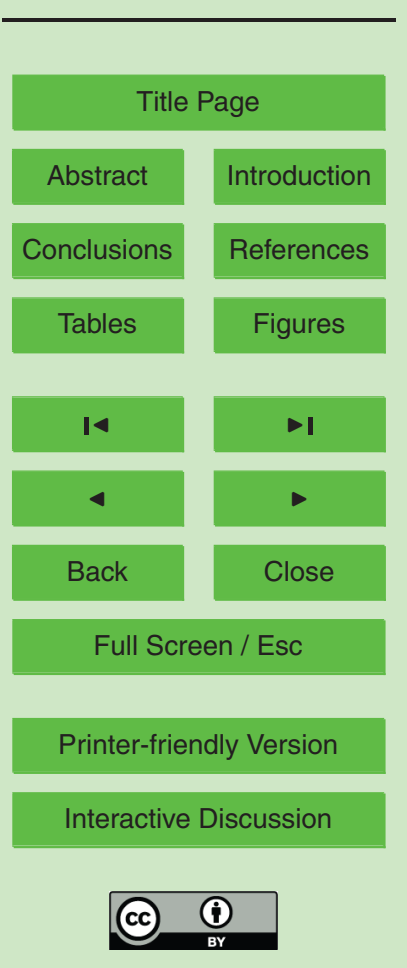


Table 5. Annual wastewater volumes within MENA generated from the eight exporting industries.

\begin{tabular}{lc}
\hline Industry & $\begin{array}{c}\text { Wastewater generated } \\
\left(\mathrm{Mm}^{3} \mathrm{yr}^{-1}\right)\end{array}$ \\
\hline Crude oil & 272 \\
Fertilizers & 208 \\
Refineries & 159 \\
Slaughterhouses & 122 \\
Potash & 24 \\
Leather (tanneries) & 4.5 \\
Pig iron & 3 \\
Olive oil & 0.7 \\
\hline Total & 793.2 \\
\hline
\end{tabular}

\section{HESSD}

10, 999-1039, 2013

\section{Virtual industrial water usage and wastewater generation}

S. R. Sakhel et al.

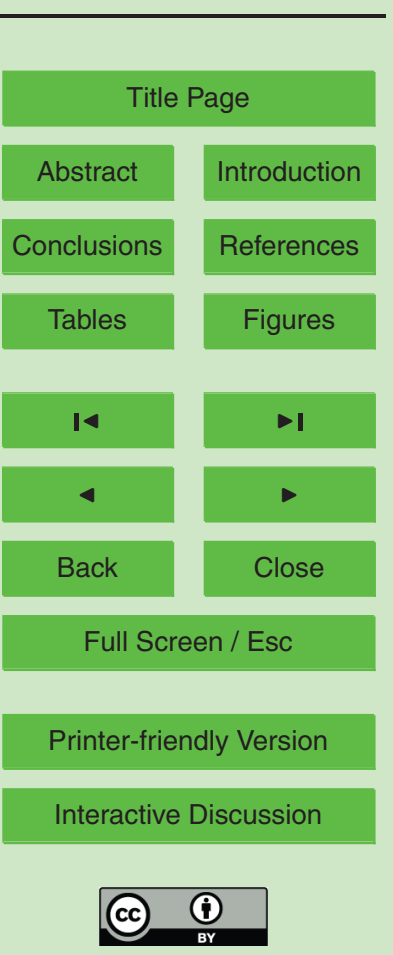


Table 6. Comparison of the estimated water usage and wastewater generation with data in the literature.

\begin{tabular}{|c|c|c|c|}
\hline Industry & Country & Water usage $\left(\mathrm{Mm}^{3} \mathrm{yr}^{-1}\right)$ & Wastewater generation $\left(\mathrm{Mm}^{3} \mathrm{yr}^{-1}\right)$ \\
\hline Refineries & Syria & $\begin{array}{l}11.5 \text { (This work: estimated water usage of } \\
\text { Homs refinery in 2004) } \\
14.9 \text { (Alahmad M., 2005, water usage for } \\
\text { Homs refinery in 2005) }\end{array}$ & \\
\hline Refineries & Israel & & $\begin{array}{l}2.95 \text { (This work: wastewater flow for } \\
\text { Haifa refinery in 2006) } \\
3.03 \text { (Brigden and Stringer 2002, } \\
\text { wastewater flow of Haifa refinery in } \\
\text { 2001) }\end{array}$ \\
\hline Refineries & Jordan & & $\begin{array}{l}1.78 \text { (This work: wastewater flow for } \\
\text { Jordan Petroleum Refinery) } \\
1.40 \text { (Mohsen and Jaber 2002, waste- } \\
\text { water flow of Jordan Petroleum Refin- } \\
\text { ery) }\end{array}$ \\
\hline $\begin{array}{l}\text { Poultry } \\
\text { slaughter- } \\
\text { houses }\end{array}$ & Syria & & $\begin{array}{l}4.4 \text { (This work: for the year 2001) } \\
5.0 \text { (Alsubuh, 2009; Da'ood, 2009) }\end{array}$ \\
\hline Tanneries & Israel & $\begin{array}{l}0.119 \text { (This work: for the year 2000) } \\
0.100 \text { (Ministry of Environment-Spain, } \\
2000 \text {, for the year 2000) }\end{array}$ & \\
\hline Olive oil & Tunisia & & $\begin{array}{l}0.47 \text { (This work: for the year 2004/ } \\
2005) \\
0.55 \text { (Mekki et al., 2003) }\end{array}$ \\
\hline Crude oil & $\begin{array}{l}\text { Saudi } \\
\text { Arabia }\end{array}$ & $\begin{array}{l}355 \text { (This work: water required to repres- } \\
\text { surise Al Ghawar field in Saudi Arabia) } \\
406 \text { (Durham, 2005, water required to re- } \\
\text { pressurise Al Ghawar field that produces } \\
\text { half of the crude oil) }\end{array}$ & \\
\hline
\end{tabular}

HESSD

10, 999-1039, 2013

\section{Virtual industrial water usage and wastewater generation}

S. R. Sakhel et al.

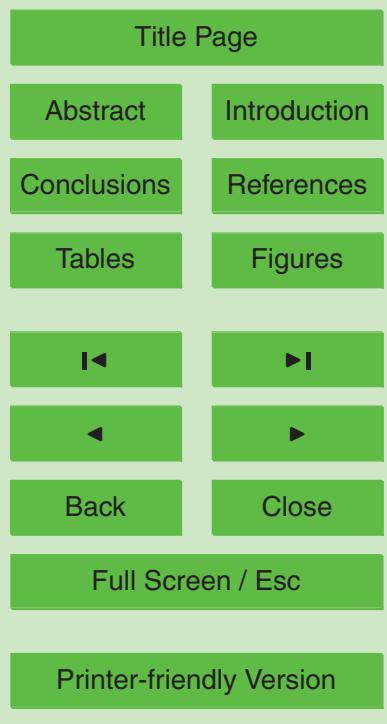

Interactive Discussion 
Table 7. Virtual water export and wastewater generation from export of crude oil for eleven MENA countries.

\begin{tabular}{lccc}
\hline Country & $\begin{array}{c}\text { Virtual water } \\
\text { exported related to } \\
\text { crude oil }\left(\mathrm{Mm}^{3} \mathrm{yr}^{-1}\right)\end{array}$ & $\begin{array}{c}\text { Wastewater } \\
\text { generated from } \\
\text { export }\left(\mathrm{Mm}^{3} \mathrm{yr}^{-1}\right)\end{array}$ & $\begin{array}{c}\text { Virtual water } \\
\text { export/domestic water } \\
\text { withdrawal (\%) }\end{array}$ \\
\hline Saudi & 79.3 & 11.90 & 4.6 \\
Arabia & 67.6 & 10.20 & 11.3 \\
Libya & 42.8 & 6.40 & 0.8 \\
Iran & 32.7 & 4.90 & 2.5 \\
Algeria & 28.2 & 4.20 & 2.2 \\
Iraq & 27.7 & 4.20 & 4.6 \\
Syria & 12.6 & 1.90 & 6.3 \\
Kuwait & 6.3 & 0.90 & 0.1 \\
Egypt & 3.2 & 0.50 & 0.9 \\
Tunisia & 0.4 & 0.06 & 0.1 \\
UAE & 0.3 & 0.05 & 0.1 \\
Yemen & 301.0 & 45.00 & 1.7 \\
\hline Total & & &
\end{tabular}

\section{HESSD}

10, 999-1039, 2013

\section{Virtual industrial water usage and wastewater generation}

S. R. Sakhel et al.

\section{Title Page}

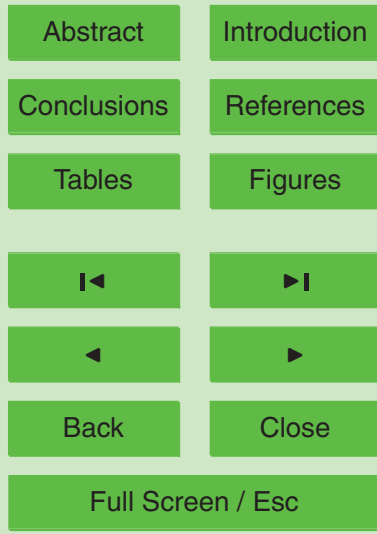

Printer-friendly Version

Interactive Discussion 


\section{HESSD}

10, 999-1039, 2013

Table 8. Water and virtual water statistics for MENA countries.

\begin{tabular}{lcccccc}
\hline Country & $\begin{array}{c}\text { Water used } \\
\text { for the } \\
\text { industry } \\
\left(\mathrm{km}^{3} \mathrm{yr}^{-1}\right)\end{array}$ & $\begin{array}{c}\text { Virtual } \\
\text { water } \\
\text { exported } \\
\left(\mathrm{Mm}^{3} \mathrm{yr}^{-1}\right)\end{array}$ & $\begin{array}{c}\text { Virtual } \\
\text { water } \\
\text { export/water } \\
\text { used }(\%)\end{array}$ & $\begin{array}{c}\text { Total actual } \\
\text { renewable water } \\
\text { resources } \\
\left(\mathrm{km}^{3} \mathrm{yr}^{-1}\right)\end{array}$ & $\begin{array}{c}\text { Virtual water } \\
\text { export/total } \\
\text { actual } \\
\text { renewable } \\
\text { water }(\%)\end{array}$ & $\begin{array}{c}\text { Water used for } \\
\text { industry/total } \\
\text { actual }\end{array}$ \\
\hline Algeria & 0.154 & 46.93 & 30.5 & 14.30 & 0.33 & $\begin{array}{c}\text { renewable } \\
\text { water }(\%)\end{array}$ \\
Bahrain & 0.030 & 0.96 & 3.2 & 0.10 & 0.96 & 3.08 \\
Egypt & 0.186 & 14.08 & 7.6 & 58.30 & 0.02 & 0.32 \\
Iran & 0.451 & 43.26 & 9.6 & 137.50 & 0.03 & 0.33 \\
Iraq & 0.137 & 28.25 & 20.7 & 75.40 & 0.04 & 0.18 \\
Israel & 0.083 & 14.90 & 18.0 & 1.70 & 0.88 & 4.88 \\
Jordan & 0.018 & 0.66 & 3.6 & 0.90 & 0.07 & 2.00 \\
Kuwait & 0.273 & 19.27 & 7.1 & 0.02 & 96.35 & 1363.95 \\
Lebanon & 0.018 & 4.36 & 24.4 & 4.40 & 0.10 & 0.41 \\
Libya & 0.166 & 86.98 & 52.4 & 0.60 & 14.50 & 27.66 \\
Morocco & 0.333 & 14.24 & 4.3 & 29.00 & 0.05 & 1.15 \\
Oman & 0.009 & 0.019 & 0.2 & 1.00 & 0.00 & 0.91 \\
Qatar & 0.034 & 0.33 & 1.0 & 0.10 & 0.33 & 34.23 \\
Saudi Arabia & 0.943 & 82.34 & 8.7 & 2.40 & 3.43 & 39.29 \\
Syria & 0.062 & 29.93 & 48.6 & 26.30 & 0.11 & 0.23 \\
Tunisia & 0.219 & 20.05 & 9.2 & 4.60 & 0.44 & 4.76 \\
UAE & 0.226 & 1.79 & 0.8 & 0.20 & 0.89 & 112.93 \\
Yemen & 0.042 & 0.36 & 0.9 & 4.10 & 0.01 & 1.03 \\
\hline Total & 3.383 & 408.72 & 12.1 & 360.92 & 0.11 & 0.94 \\
\hline & & & & & & \\
\hline
\end{tabular}

\section{Virtual industrial water usage and wastewater generation}

S. R. Sakhel et al.

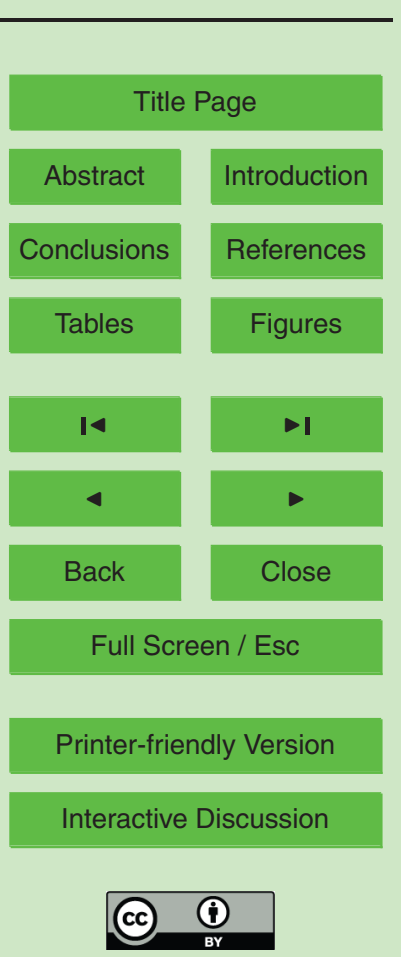


Table 9. Pollution of the different industries studied in the relevant countries in terms of BOD.

\begin{tabular}{|c|c|c|c|c|}
\hline Industry & Typical $\mathrm{BOD}_{5}$ values & Reference & Quantities & $\begin{array}{l}\text { Pollution in terms of } \\
\text { BOD }\left(\mathrm{tyr}^{-1}\right) \text { due to } \\
\text { production }\end{array}$ \\
\hline Crude oil & $\begin{array}{l}50-1400 \mathrm{mg} \mathrm{L}^{-1} \\
\text { selected: } 725 \mathrm{mg} \mathrm{L}^{-1}\end{array}$ & Wang et al. (2004) & 272 Mio $^{3} a^{-1}$ & 197200 \\
\hline Meat & & IPPC (2005) & & 93297 \\
\hline Sheep, goat & $8.89 \mathrm{~kg} \mathrm{BOD}_{5} \mathrm{t}^{-1}$ & & $1020410 \mathrm{ta}^{-1}$ & \\
\hline Cattle & $\begin{array}{l}1.8-28 \mathrm{~kg} \mathrm{BOD} \mathrm{t}^{-1} \\
\text { selected: } 14.9 \mathrm{~kg} \mathrm{BOD} \mathrm{t}^{-1}\end{array}$ & & $1070284 \mathrm{ta}^{-1}$ & \\
\hline Poultry & $\begin{array}{l}2.43-43 \mathrm{~kg} \mathrm{BOD} \mathrm{t}^{-1} \\
\text { selected: } 22.715 \mathrm{~kg} \mathrm{BOD}_{5} \mathrm{t}^{-1}\end{array}$ & & $3005869 \mathrm{ta}^{-1}$ & \\
\hline Refineries & $\begin{array}{l}150-250 \mathrm{mg} \mathrm{BOD} \mathrm{L}^{-1} \\
\text { selected: } 200 \mathrm{mg} \mathrm{BOD}_{5} \mathrm{~L}^{-1}\end{array}$ & $\begin{array}{l}\text { World Bank Group } \\
\text { (1998) }\end{array}$ & 159.1 Mio $\mathrm{m}^{3} \mathrm{a}^{-1}$ & 31820 \\
\hline Olive oil & $\begin{array}{l}32.254 \mathrm{mg} \mathrm{BOD}_{5} \mathrm{~L}^{-1} \\
\text { (average value) }\end{array}$ & $\begin{array}{l}\text { Niaounakis and } \\
\text { Halvadakis (2006) }\end{array}$ & 0.705 Mio $^{3} \mathrm{a}^{-1}$ & 22739 \\
\hline Leather & & IPPC (2001b) & & 8592 \\
\hline Goat skins & $\begin{array}{l}48-86 \mathrm{~kg} \mathrm{BOD} \mathrm{t}^{-1} \\
\text { Selected: } 67 \mathrm{~kg} \mathrm{BOD}_{5} \mathrm{t}^{-1}\end{array}$ & & $5254.5 \mathrm{ta}^{-1}$ & \\
\hline Sheep skins & $60.75 \mathrm{~kg} \mathrm{BOD}_{5} \mathrm{t}^{-1}$ & & $29350.5 \mathrm{ta}^{-1}$ & \\
\hline Bovine hide & $\begin{array}{l}\text { 48-86 kg BOD } \mathrm{t}^{-1} \\
\text { Selected: } 67 \mathrm{BOD}_{5} \mathrm{t}^{-1}\end{array}$ & & $96367 \mathrm{ta}^{-1}$ & \\
\hline Fertilizers & & & & 5443 \\
\hline Nitrogenous & $20 \mathrm{mg} \mathrm{BOD}_{5} \mathrm{~L}^{-1}$ & $\begin{array}{l}\text { Kamaldeep et al. } \\
\text { (1993) }\end{array}$ & 25.6 Mio $\mathrm{m}^{3} \mathrm{a}^{-1}$ & \\
\hline Phosphatic & $\begin{array}{l}\text { 18-36 mg BOD } \mathrm{L}^{-1} \\
\text { selected: } 27 \mathrm{mg} \mathrm{BOD} \mathrm{L}^{-1}\end{array}$ & Sayadi et al. (2008) & 182.6 Mio $\mathrm{m}^{3} \mathrm{a}^{-1}$ & \\
\hline Pig iron & $160 \mathrm{mg} \mathrm{BOD}_{5} \mathrm{~L}^{-1}$ & Jena et al. (2005) & 3.1 Mio $\mathrm{m}^{3} \mathrm{a}^{-1}$ & 496 \\
\hline Potash & 15 & Hacĕne et al. (2004) & 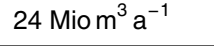 & 360 \\
\hline Total & & & & 359947 \\
\hline
\end{tabular}

HESSD

10, 999-1039, 2013

\section{Virtual industrial water usage and wastewater generation}

S. R. Sakhel et al.

\section{Title Page}

\begin{tabular}{|c|c|}
\hline Abstract & Introduction \\
\hline Conclusions & References \\
\hline Tables & Figures \\
\hline I4 & \\
\hline 4 & - \\
\hline Back & Close \\
\hline
\end{tabular}

Full Screen / Esc

Printer-friendly Version

Interactive Discussion 


\section{HESSD}

10, 999-1039, 2013

\section{Virtual industrial water usage and wastewater generation}

Table 10. Indirect pollution in MENA due to export to EU27 in terms of BOD.

\begin{tabular}{lcc}
\hline Industry & $\begin{array}{c}\text { Indirect pollution } \\
\text { by EU27 in terms } \\
\text { of BOD }\left(\mathrm{t} \mathrm{yr}^{-1}\right)\end{array}$ & $\begin{array}{c}\text { Population } \\
\text { equivalent in } \\
\text { terms of BOD }\end{array}$ \\
\hline Crude oil & 32625 & 2314730 \\
Olive oil & 10122 & 749466 \\
Leather & 6333 & 446842 \\
Refineries & 2360 & 169214 \\
Fertilizers & 244 & 17799 \\
Meat & 101 & 6929 \\
Potash & 38 & 2603 \\
Pig iron & 24 & 1742 \\
\hline Total & 51847 & 3709325 \\
\hline
\end{tabular}

S. R. Sakhel et al.

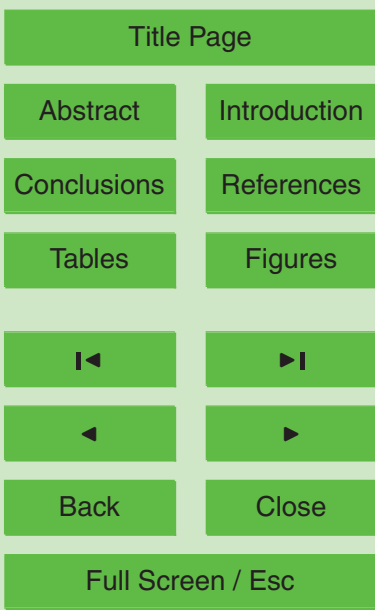

Printer-friendly Version

Interactive Discussion 


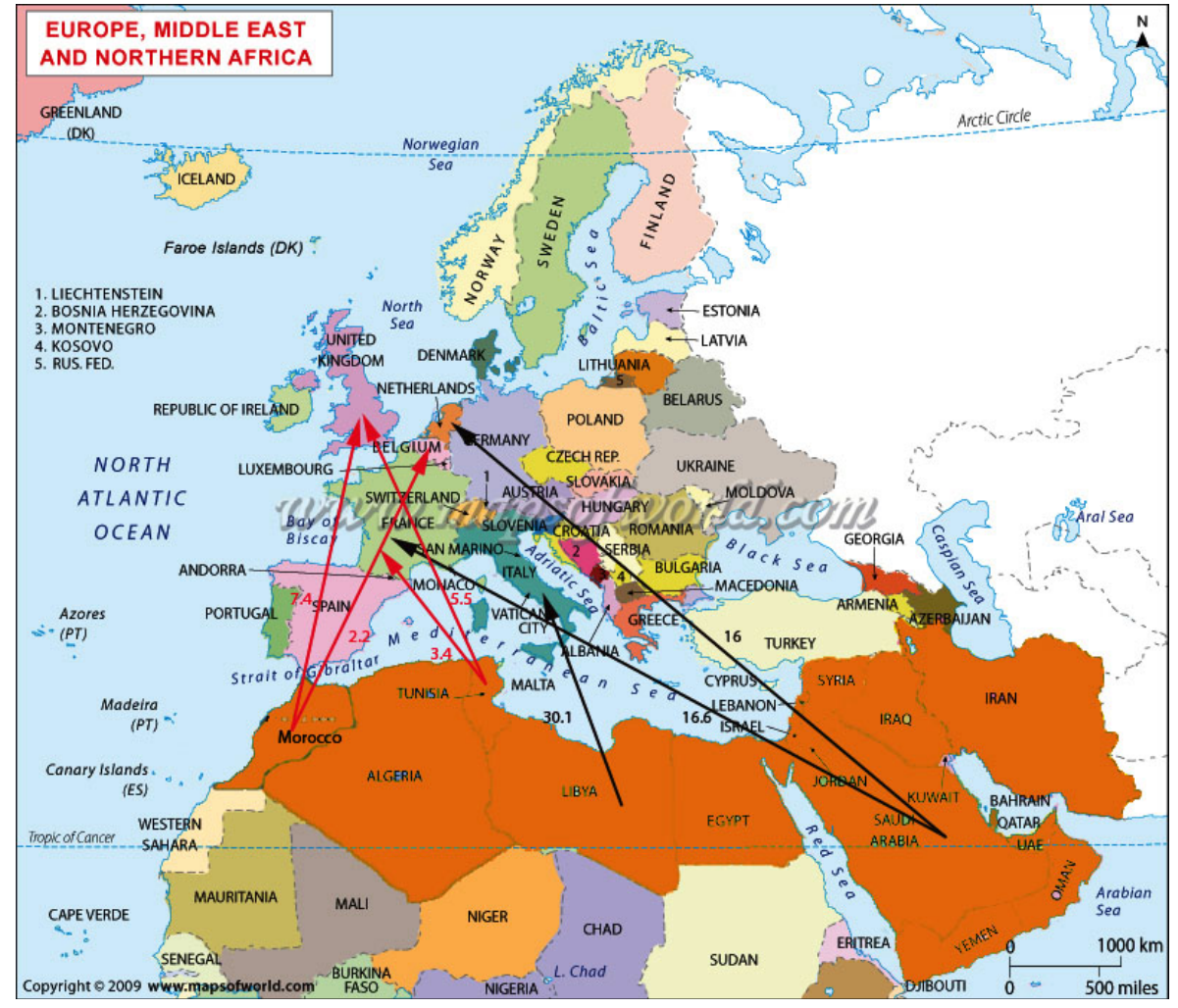

Fig. 1. Virtual water flows from four MENA exporting countries (dark orange color) to five EU27 countries in the field of crude oil (black) and phosphatic fertilizers (red): numbers are million cubicmeters of virtual water exported in 2001 for crude oil and 2010 for phosphatic fertilizers. Saudi Arabia and Libya are the largest exporters in the field of crude oil and Morocco/Tunisia are the largest exporters in the field of phosphatic fertilizers.

\section{HESSD}

10, 999-1039, 2013

\section{Virtual industrial water usage and wastewater generation}

S. R. Sakhel et al.

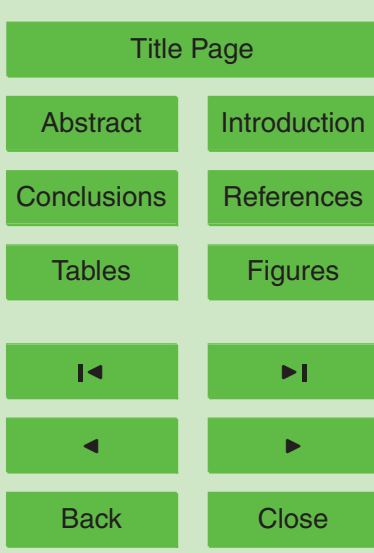

Full Screen / Esc

Printer-friendly Version

Interactive Discussion 